Provided for non-commercial research and education use. Not for reproduction, distribution or commercial use.

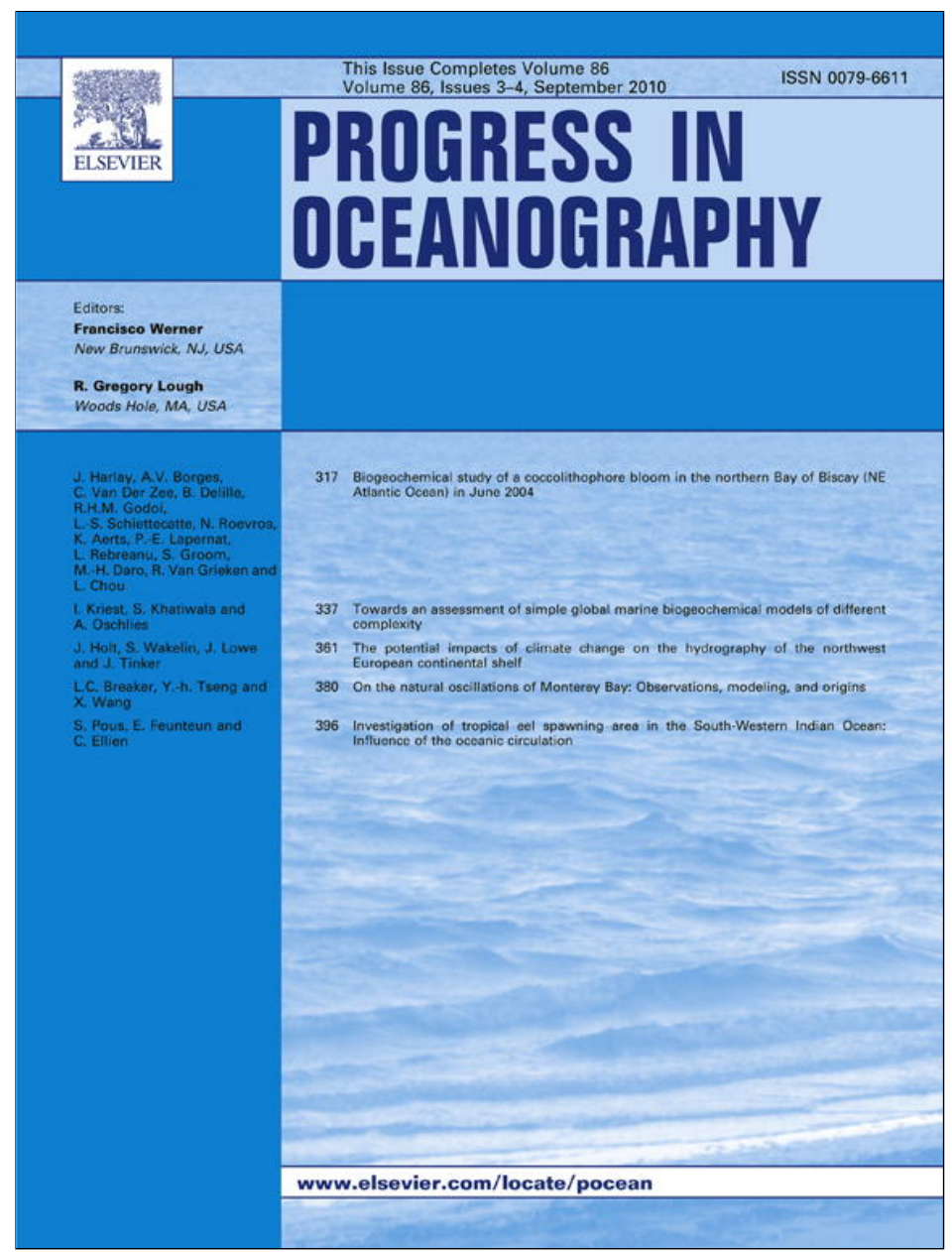

This article appeared in a journal published by Elsevier. The attached copy is furnished to the author for internal non-commercial research and education use, including for instruction at the authors institution and sharing with colleagues.

Other uses, including reproduction and distribution, or selling or licensing copies, or posting to personal, institutional or third party websites are prohibited.

In most cases authors are permitted to post their version of the article (e.g. in Word or Tex form) to their personal website or institutional repository. Authors requiring further information regarding Elsevier's archiving and manuscript policies are encouraged to visit:

http://www.elsevier.com/copyright 


\title{
Biogeochemical study of a coccolithophore bloom in the northern Bay of Biscay (NE Atlantic Ocean) in June 2004
}

\author{
J. Harlay a,b,* A.V. Borges ${ }^{b}$, C. Van Der Zee ${ }^{a}$, B. Delille ${ }^{\text {b }}$, R.H.M. Godoi ${ }^{\text {c,d }}$, L.-S. Schiettecatte ${ }^{b}$, N. Roevros ${ }^{\text {a }}$, \\ K. Aerts ${ }^{\text {c }}$, P.-E. Lapernat ${ }^{\text {e }}$, L. Rebreanu ${ }^{\text {a }}$, S. Groom ${ }^{\text {f }}$, M.-H. Daro ${ }^{\mathrm{e}}$, R. Van Grieken ${ }^{\mathrm{c}}$, L. Chou ${ }^{\mathrm{a}}$ \\ ${ }^{a}$ Laboratoire d'Océanographie Chimique et Géochimie des Eaux, Université Libre de Bruxelles, Campus de la Plaine, CP 208, Boulevard du Triomphe, B-1050 Brussels, Belgium \\ ${ }^{\mathrm{b}}$ Chemical Oceanography Unit, Université de Liège, University of Liège, Institut de Physique (B5), B-4000 Sart Tilman, Belgium \\ ${ }^{\mathrm{c}}$ Department of Chemistry, University of Antwerp, Universiteitsplein 1, D.B.207, B-2610 Wilrijk, Belgium \\ ${ }^{\mathrm{d}}$ Federal University of Paraná, Environmental Engineering Department. Rua Francisco H. dos Santos 100 Jardim das Américas, $81531-990$ Curitiba, PR, Brazil \\ ${ }^{\mathrm{e}}$ Ecology and Systematics, Vrij Universiteit Brussel, Pleinlaan 2, B-1050 Brussels, Belgium \\ ${ }_{\mathrm{f}}^{\mathrm{f}}$ Remote Sensing Group, Plymouth Marine Laboratory, Prospect Place, The Hoe, Plymouth PL1 3DH, United Kingdom
}

\section{A R T I C L E I N F O}

\section{Article history:}

Received 9 March 2009

Received in revised form 9 April 2010

Accepted 9 April 2010

Available online 19 April 2010

\begin{abstract}
A B S T R A C T
The present paper synthesizes data obtained during a multidisciplinary cruise carried out in June 2004 at the continental margin of the northern Bay of Biscay. The data-set allows to describe the different stages of a coccolithophore bloom dominated by Emiliania huxleyi. The cruise was carried out after the main spring phytoplankton bloom that started in mid-April and peaked in mid-May. Consequently, low phosphate $\left(\mathrm{PO}_{4}<0.2 \mu \mathrm{M}\right)$ and silicate $(\mathrm{DSi}<2.0 \mu \mathrm{M})$ concentrations, low partial pressure of carbon dioxide $\left(\mathrm{pCO}_{2}\right)$ and high calcite saturation degree in surface waters combined with thermal stratification, probably favoured the blooming of coccolithophores. During the period of the year our cruise was carried out, internal tides induce enhanced vertical mixing at the continental shelf break leading to the injection of inorganic nutrients to surface waters that probably trigger the bloom. The bloom developed as the water-column stratified and as the water mass was advected over the continental shelf, following the general residual circulation in the area. The most developed phase of the bloom was sampled in a remote sensed high reflectance (HR) patch over the continental shelf that was characterized by low chlorophyll-a (Chl-a) concentration in surface waters $\left(<1.0 \mu \mathrm{g} \mathrm{L}^{-1}\right)$, high particulate inorganic carbon (PIC) concentration $\left(\sim 8 \mu \mathrm{mol} \mathrm{L}^{-1}\right)$ and coccolithophore abundance up to $57 \times 10^{6}$ cells $\mathrm{L}^{-1}$. Transparent exopolymer particles (TEP) concentrations ranged between 15 and $75 \mu \mathrm{g} \mathrm{C} \mathrm{L}{ }^{-1}$ and carbon content of TEP represented up to $26 \%$ of the particulate organic carbon (POC; maximum concentration of $15.5 \mu \mathrm{mol} \mathrm{L}^{-1}$ in the upper $40 \mathrm{~m}$ ). Integrated primary production (PP) ranged between 210 and $680 \mathrm{mg} \mathrm{C} \mathrm{m}^{-2} \mathrm{~d}^{-1}$ and integrated calcification (CAL) ranged between 14 and $140 \mathrm{mg} \mathrm{C} \mathrm{m}^{-2} \mathrm{~d}^{-1}$, within the range of PP and CAL values previously reported during coccolithophore blooms in open and shelf waters of the North Atlantic Ocean. Bacterial protein production (BPP) measurements in surface waters $\left(0.3-0.7 \mu \mathrm{g} \mathrm{L} \mathrm{L}^{-1} \mathrm{~h}^{-1}\right)$ were much higher than those reported during early phases of coccolithophore blooms in natural conditions, but similar to those during peak and declining coocolithophorid blooms reported in mesocosms. Total alkalinity anomalies with respect to conservative mixing $(\Delta \mathrm{TA})$ down to $-49 \mu \mathrm{mol} \mathrm{kg}^{-1}$ are consistent with the occurrence of biogenic precipitation of calcite, while $\mathrm{pCO}_{2}$ remained 15-107 $\mu \mathrm{atm}$ lower than atmospheric equilibrium ( $372 \mu \mathrm{atm}$ ). The correlation between $\Delta \mathrm{TA}$ and $\mathrm{pCO}_{2}$ suggested that $\mathrm{pCO}_{2}$ increased in part due to calcification, but this increase was insufficient to overcome the background under-saturation of $\mathrm{CO}_{2}$. This is related to the biogeochemical history of the water masses due to net carbon fixation by the successive phytoplankton blooms in the area prior to the cruise, hence, the investigated area remained a sink for atmospheric $\mathrm{CO}_{2}$ despite calcification.
\end{abstract}

(c) 2010 Elsevier Ltd. All rights reserved. * Corresponding author at: Laboratoire d'Océanographie Chimique et Géochimie
des Eaux, Université Libre de Bruxelles, Campus de la Plaine, CP 208, Boulevard du
Triomphe, B-1050 Brussels, Belgium.

E-mail addresses: jerome.harlay@ulg.ac.be, jharlay@ulb.ac.be (J. Harlay).

\section{Introduction}

Primary production sustains the so-called organic carbon pump that corresponds to the transfer of organic carbon from surface to deeper waters. Pelagic calcification counter-acts the carbon dioxide $\left(\mathrm{CO}_{2}\right)$ uptake related to primary production by decreasing surface water total alkalinity (TA), leading to a shift in inorganic 
carbon chemistry from the bicarbonate pool to the $\mathrm{CO}_{2}$ pool ("releasing" $\mathrm{CO}_{2}$ to water column), according to:

$2 \mathrm{HCO}_{3}^{-}+\mathrm{Ca}^{2+} \leftrightarrow \mathrm{CaCO}_{3}+\mathrm{CO}_{2}+\mathrm{H}_{2} \mathrm{O}$

Calcite $\left(\mathrm{CaCO}_{3}\right)$ also acts as a ballast mineral for marine organic particles, increasing their sinking rate to deeper waters, and is thought to increase the long-term storage of carbon (C) (Honjo et al., 2008). The $C$ storage efficiency in a marine ecosystem is given by the ratio of the export of particulate inorganic (PIC) to organic (POC) carbon, the PIC:POC "rain ratio", which is proportional to the net balance in surface waters of photosynthesis/respiration and of calcification/ $\mathrm{CaCO}_{3}$ dissolution. Seasonal blooms of the coccolithophore Emiliania huxleyi Lohman (Hay et Mohler) can cover areas of hundreds of square kilometres in temperate and sub-polar regions (e.g. Brown and Yoder, 1994). Emiliania huxleyi is the most abundant bloomforming calcifier in the North Atlantic Ocean and the major pelagic producer of $\mathrm{CaCO}_{3}$ in the contemporary open ocean (Westbroek et al., 1993). During its life cycle, E. huxleyi produces $\mathrm{CaCO}_{3}$ coccoliths covering the cell that are continuously released into the surrounding water (Fritz and Balch, 1996). Suspended coccoliths in surface waters scatter light, producing bright "milky" waters, that allow the detection of coccolithophore blooms by remote sensing (Balch et al., 1991, 2005, 2007; Brown and Yoder, 1994; Tyrrell et al., 1999; Gordon and Du, 2001; Merico et al., 2003; Smyth et al., 2004). Such blooms offer the opportunity to investigate the coupling of photosynthesis and calcification in natural assemblages, complementing laboratory (e.g. Zondervan et al., 2002; Sciandra et al., 2003) and mesocosms experiments (Delille et al., 2005; Engel et al., 2005) in order to better understand current biogeochemical cycling of $\mathrm{C}$ in the ocean and predict its future evolution.

Balch et al. (2007) recently estimated global pelagic calcification to be $1.6 \pm 0.3 \mathrm{Pg} \mathrm{PIC} \mathrm{yr}^{-1}$ ( 1 Petagram $=10^{15} \mathrm{~g}$ ), based on remote sensing data. This would imply that coccolithophores would be the single most important pelagic calcifier in the oceans, as other estimates of global pelagic calcification range between 0.7 Pg PIC $\mathrm{yr}^{-1}$ based on historical accumulation rates and sedi-

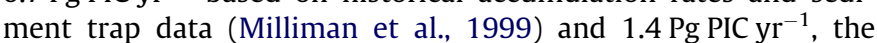
upper-most value based on the analysis of the seasonal cycle of TA in the euphotic zone (Lee, 2001). Yet, uncertainties remain regarding the intensity of coccolithophore calcification, bloom development, and contribution to the bulk vertical flux of $\mathrm{CaCO}_{3}$ to depth. For instance, $\mathrm{CaCO}_{3}$ dissolution was shown to occur on short time scales in the top $1000 \mathrm{~m}$ of the water column (Wollast and Chou, 1998; Milliman et al., 1999), and possibly also in the photic zone (Beaufort et al., 2007). The global average of sediment-trap based estimates of $\mathrm{CaCO}_{3}$ sedimentation at $2000 \mathrm{~m}$ is $0.4 \mathrm{Pg} \mathrm{PIC} \mathrm{yr}^{-1}$ (Honjo et al., 2008), implying a loss of biogenic $\mathrm{CaCO}_{3}$ by dissolution above that depth of up to $75 \%$ (based on

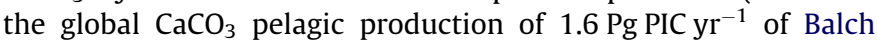
et al., 2007), in agreement with other independent estimates (Feely et al., 2002; Sabine et al., 2002). Several mechanisms were put forward by Milliman et al. (1999) to account for the $60 \%$ decrease of $\mathrm{CaCO}_{3}$ in the top $1000 \mathrm{~m}$ of the ocean, including the formation of fast sinking aggregates (i.e. faecal pellets) or the dissolution of $\mathrm{CaCO}_{3}$ in digestive tracts of grazers.

Particle aggregation occurs at high cell densities and elevated concentration of colloids during phytoplankton blooms (Verdugo et al., 2004) and contribute to the efficient export of $C$ to depth (De La Rocha and Passow, 2007). Among the marine aggregates, precursors of transparent exopolymer particles (TEP) originate from phytoplankton exudates, and have been described during blooms of diatoms (Mopper et al., 1995; Passow and Alldredge, 1995a,b; Engel and Schartau, 1999; Bhaskar et al., 2005), of Phaeocystis (Mari et al., 2005) and of E. huxleyi in mesocosms (Engel et al., 2004,2005 ) and in natural conditions (Harlay et al., 2009).The sig- nificance of TEP in biogeochemical C cycling in the upper water column is due to their colloidal structure (Passow, 2002), and their sticky properties that alter the number, size and density of particles in the ocean by aggregation of suspended material. Aggregation favours the formation of larger particles (Chin et al., 1998) that may either be ingested by zooplankton (Passow and Alldredge, 1999; Ling and Alldredge, 2003) or rapidly exported to depth as marine snow (Cadée, 1985; Riemann, 1989; van der Wal et al., 1995). The particles incorporating TEP may host specific bacterial communities (Alldredge et al., 1986; Mari and Kiorboe, 1996) on which they grow (Mari and Rassoulzadegan, 2004), and also be associated with ciliates (Mari and Rassoulzadegan, 2004), copepods or crustacean larvae (Kiorboe, 2000).

In June 2004, extensive blooms of E. huxleyi were detected by remote sensing at the continental margin of the Bay of Biscay and stretched along the continental shelf break from the southern Bay of Biscay to the Irish coast (Fig. 1d). The present paper reports data acquired during a multidisciplinary biogeochemical cruise, carried out with remote sensing guidance, during a coccolithophore bloom dominated by E. huxleyi, at the continental margin of the northern Bay of Biscay. Measurements were taken over the continental slope and shelf on the physical vertical structure (temperature and salinity), inorganic nutrient profiles (phosphate and silicate), oxygen saturation $\left(\% \mathrm{O}_{2}\right)$, dissolved inorganic carbon (DIC) variables, the standing stocks of POC, TEP and PIC, densities of coccolithospheres and coccoliths, primary production (PP) and calcification (CAL) rates, protein production rates (BPP) and bacterial abundances. We focus on the description of the biogeochemical settings and $C$ fluxes at different stations at the continental shelf break and on the continental shelf that correspond to different stages of bloom development. We also try to unravel the physical and biogeochemical factors that drive in late spring/early summer the onset and decline of coccolithophore blooms in the area.

\section{Material and methods}

\subsection{Sampling area and cruise data}

Cruise BG04/13 was carried out onboard the RV Belgica in early June 2004, in the northern Bay of Biscay, and was divided in two legs (1-10 June and 13-17 June) during which three stations, termed "bis", were re-visited (stations 4bis, 5bis and 7bis; Fig. 1a). Between the two legs of the cruise, a major storm occurred in the area. The investigated area covered the continental margin (Armorican shelf), where high reflectance (HR) was observed on remote sensed images (Fig. 1d). This area, from the Goban Spur (north) to the La Chapelle Bank (south), has been extensively investigated for physics and biogeochemistry during the European project Ocean Margin Exchange (OMEX; Wollast and Chou, 2001a,b). Background information in the study area is given for physics by Huthnance et al. (2001), for pelagic primary production by Joint et al. (2001), for the composition of particles by McCave et al. (2001) and for C cycling by Wollast and Chou (2001b).

\subsection{Vertical hydrographic structure and water sampling}

A Seabird conductivity-temperature-depth (CTD) probe equipped with a rosette sampler of $1210 \mathrm{~L}$ Niskin bottles was used to determine depth profiles of temperature and salinity, and collect seawater for chemical analyses at 10 stations covering the continental shelf and slope of the northern Bay of Biscay. Discrete samples were collected in the morning (between 4:00 and 6:00 universal time coordinated (UTC)) at $3,10,20,40,60,80,100$ and $150 \mathrm{~m}$. Some additional depths were occasionally sampled in 

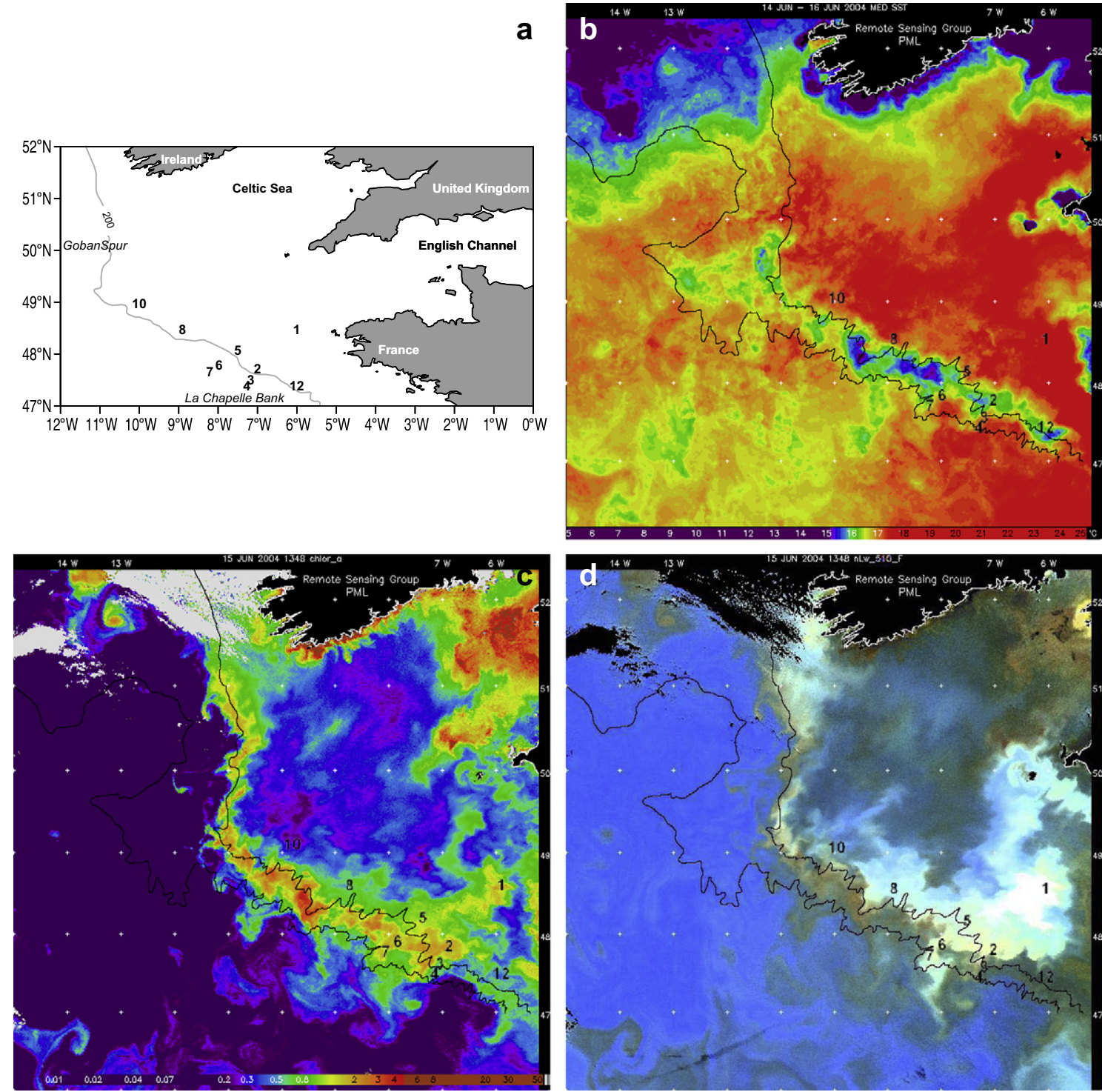

Fig. 1. (a) Map of the study site showing the location of the stations and the continental shelf break (200 $\mathrm{m}$ isobath). Stations $1-10 \mathrm{mere}$ visited during the first leg ( $3-10$ June 2004). Station 12 was visited during the second leg (12-18 June 2004) and stations 4, 7 and 5 were re-visited after 10 d. (b) Advanced Very High Resolution Radiometer satellite image of sea surface temperature (composite of 14-16 June 2004) showing a cooling of surface waters along the continental shelf break. (c) Sea-viewing Wide Fieldof-view Sensor (SeaWiFS) image of sea surface chlorophyll-a distribution (15 June 2004) showing a phytoplankton bloom along the continental shelf break. (d) SeaWiFS falsecolour composite image (443, 490 and $555 \mathrm{~nm}$ bands, 15 June 2004) showing a bloom of coccolithophore along the continental shelf break. Higher reflectance patches are represented in turquoise to white.

the surface layer (50 $\mathrm{m}$ and $120 \mathrm{~m}$ ) and deeper (down to $1200 \mathrm{~m}$ ) at the stations located on the slope. Vertical profiles of the photosynthetically active radiation (PAR) were obtained daily around noon (UTC) at each station using Seabird SBE19 CTD equipped with a Li-Cor quantum sensor.

\subsection{Nutrients}

Dissolved phosphate $\left(\mathrm{PO}_{4}\right)$ and dissolved silicate (DSi) concentrations were measured spectrophotometrically with the molybdate/ascorbic acid method described by Grasshoff et al. (1983), on samples filtered on $0.4 \mu \mathrm{m}$ Nuclepore filters and kept at $-20{ }^{\circ} \mathrm{C}\left(\mathrm{PO}_{4}\right)$ or at $4{ }^{\circ} \mathrm{C}(\mathrm{DSi})$ until analysis.

\subsection{Oxygen saturation $\left(\% \mathrm{O}_{2}\right)$}

Concentration of dissolved $\mathrm{O}_{2}$ was measured by automated Winkler titration with potentiometric end-point detection using a Metrohm redox electrode (6.0451.100) and Metrohm titrator
(Dosimat 625). Reagents and standardizations were similar to those described by Knap et al. (1996). The saturation concentration of seawater with respect to oxygen was computed with the algorithm given by Benson and Krause (1984).

\subsection{Carbonate system}

TA was measured on board by potentiometric titration (Gran, 1952 ) with $0.1 \mathrm{M} \mathrm{HCl}$ on $100 \mathrm{ml}(\mathrm{GF} / \mathrm{F}$, Whatman) filtered seawater. $\mathrm{pH}$ was measured on the total hydrogen ion scale (Dickson et al., 2007) using a Ross type combined electrode (ORION ${ }^{\circledR}$ ) calibrated with TRIS (2-amino-2-hydroxymethyl-1,3-propanediol) and AMP (2-aminopyrodine) buffers in synthetic seawater of a salinity of 35 . The saturation state with respect to calcite ( $\left.\Omega_{\text {calcite }}\right)$ was computed from $\mathrm{pH}$ and TA with the CO2sys package (Lewis and Wallace, 1998), using the carbonic acid constants of Mehrbach et al. (1973), the dissociation constant of boric acid from Dickson (1990), and the calcite solubility of Mucci (1983). In addition to vertical profiles sampled from Niskin bottles, underway (UW) 
samples of TA were obtained from the seawater supply of the ship at $3 \mathrm{~m}$ depth.

Underway measurements of $\mathrm{pCO}_{2}$ in surface waters $(3 \mathrm{~m})$ were carried out using an equilibrator (Frankignoulle et al., 2001) and an infra-red $\mathrm{CO}_{2}$ analyzer. The infra-red $\mathrm{CO}_{2}$ analyzer (Li-Cor 6262) was calibrated with pure nitrogen (Air Liquide Belgium) and two gas mixtures with a $\mathrm{CO}_{2}$ molar fraction of 366 and $810 \mathrm{ppm}$ (Air Liquide Belgium) that were calibrated against National Oceanic and Atmospheric Administration, Global Monitoring Division, Carbon Cycle Greenhouse Gases Group standards of a $\mathrm{CO}_{2}$ molar fraction of 361 and $774 \mathrm{ppm}$. Seawater $\mathrm{pCO}_{2}$ was corrected for the difference between in situ temperature and water temperature at the outlet of the equilibrator $\left(<1{ }^{\circ} \mathrm{C}\right)$ using the algorithms of Copin-Montégut $(1988,1989)$. The overall precision of $\mathrm{pCO}_{2}$ measurements is estimated at $\pm 2 \mu \mathrm{atm}$.

\subsection{Chlorophyll-a (Chl-a) concentration}

The Chl-a concentration was determined fluorometrically according to Yentsch and Menzel (1963) in $1 \mathrm{~L}$ of seawater filtered through glass fiber filters ( $47 \mathrm{~mm}$ Whatman GF/F). Filters were stored in liquid nitrogen on board, and deep-frozen at $-80^{\circ} \mathrm{C}$ in the laboratory before analysis. Pigments extraction was carried out overnight in $5 \mathrm{ml} 90 \%$ acetone at $4{ }^{\circ} \mathrm{C}$ in the dark. Acetone extracts were centrifuged for $5 \mathrm{~min}$ at $5000 \mathrm{rpm}$ and measurements carried out with a Turner (TD-700) fluorometer.

\subsection{Colorimetric determination of TEP}

The concentration of TEP was determined spectrophotometrically according to Passow and Alldredge (1995a). Two-hundred and fifty millilitre of seawater were fixed onboard with buffered formalin ( $1 \%$ of final concentration) and kept in the dark at $4{ }^{\circ} \mathrm{C}$ until analysis. Within 6 weeks, triplicate samples (of $\sim 80 \mathrm{ml}$ ) were gently filtered ( $<200 \mathrm{mbar}$ ) on $0.4 \mu \mathrm{m}$ Nuclepore filters $(25 \mathrm{~mm})$ and stained with $0.5 \mathrm{ml}$ Alcian Blue (Sigma, $8 \mathrm{GX}$ ). Excess dye was washed out with deionised water. Attention was paid during filtration to avoid clogging. The results are the average of triplicates and are expressed in $\mu \mathrm{g}$ of Gum Xanthan equivalent per liter $\left(\mu \mathrm{g}\right.$ Xeq $\left.\mathrm{L}^{-1}\right)$. All concentrations were corrected for the adsorption of Alcian Blue with blank filters. The conversion factors of TEP to carbon content (TEP-C) range from $40 \%(\mathrm{wt} / \mathrm{wt}$ ) based on mesocosm experiments with the coccolithophore E. huxleyi (Engel et al., 2004) to $88 \%$ (wt/wt) based on a monospecific culture of the diatom Coscinodiscus wailesii (Engel and Passow, 2001), with intermediate values of $75 \%$ (wt/wt) for a natural assemblage of diatoms (Engel and Passow, 2001). Due to the wide range in the TEP to TEP-C conversion factors and the large uncertainty in the species composition of natural assemblages sampled, a conversion factor of $63 \%$ (wt/wt) was used (i.e. $0.052 \mu \mathrm{mol} \mathrm{C}(\mu \mathrm{g} \mathrm{Xeq})^{-1}$ ) given by Engel (2004) from a multispecific assemblage including E. huxleyi and diatoms. The interference on TEP measurements by the coating with stainable polysaccharides of the coccosphere of $E$. huxleyi (i.e. $2.59 \pm 0.40 \mathrm{pg} \mathrm{Xeq} \mathrm{cell}^{-1}$ in Engel et al., 2004) was negligible ( $p=0.227, n=34$ ) compared to bulk TEP concentrations measured during the present study.

\subsection{Suspended particulate matter (SPM) concentration and elemental composition}

Seawater $(0.2-2.0 \mathrm{~L})$ was filtered on pre-combusted $(4 \mathrm{~h}$, $\left.500{ }^{\circ} \mathrm{C}\right) 47 \mathrm{~mm} \mathrm{GF} / \mathrm{F}$ filters. The samples were stored onboard at $-20^{\circ} \mathrm{C}$ until analysis. Within 3 months after the cruise, the filters were dried overnight at $50{ }^{\circ} \mathrm{C}$. The filtered area was stamped out with a calibrated punch in order to randomly sub-sample six stamps per filter. Total particulate carbon (TPC) and POC were determined sequentially with a Fisons NA-1500 CHN micro-analyzer. One set of triplicate stamps were kept in solvent-rinsed Sn sample boats (for TPC analysis), while another set of triplicate samples was acidified overnight under $\mathrm{HCl}$ fumes, at room temperature, before being packed in solvent-rinsed Sn sample boats (for POC analysis). PIC was estimated as the difference between average TPC and POC values. The CHN micro-analyzer response was calibrated using 4-5 certified reference stream sediment from the Geological Survey of Canada standards and 3-4 empty Sn boat blanks to obtain a least-squares linear regression calibration line. The linearity of individual calibrations was high for carbon content $\left(r^{2}=0.99\right)$.

\subsection{Elemental X-ray analysis of suspended matter (EPXMA)}

Seawater samples $(100 \mathrm{ml})$ were filtered immediately after collection on $47 \mathrm{~mm}$ grade $0.4 \mu \mathrm{m}$ pore-size Nuclepore filters. Crystallized salts were removed by rinsing filters three times with $50 \mathrm{ml}$ of $0.05 \mathrm{M} \mathrm{NH}_{4} \mathrm{HCO}_{3}$ buffer. The filters were placed in Petri dishes, air dried and stored in a deep-freezer until preparation for scanning electron microscopy (SEM) analysis. For every sample, two pieces of filter were cut and placed on a plate; the first one was coated with $50 \mathrm{~nm}$ of carbon for automatic analysis, while the second one was coated with gold for image collection. Determination of coccospheres and coccoliths abundances was made with an automated single particle analyzer (JEOL JSM 6300 SEM) equipped for electron probe $\mathrm{X}$-ray microanalysis. Computer controlled single particle analysis by EPXMA was performed on approximately 400 particles per sample, using an accelerating voltage of $20 \mathrm{kV}$, a beam current of $1.0 \mathrm{nA}$ and a measuring time of $20 \mathrm{~s}$. X-ray spectra provided information about the chemical composition of the individual particles. The magnification of $1000 \times$, used in the measurements, determined the minimum detectable diameter (about $0.7 \mu \mathrm{m}$ ). The size fraction analyzed in each sample ranged from $0.7 \mu \mathrm{m}$ to $10.0 \mu \mathrm{m}$ encompassing the size of coccoliths and coccospheres.

For analysis and interpretation, the data of each individual sample were subjected to hierarchical cluster analysis (Bondarenko et al., 1996). The hierarchical results were then used as input for a non-hierarchical cluster analysis. The different particle groups present for each sample and their corresponding relative abundances were determined by the IDAS program as described by Bondarenko et al. (1996). Ca-rich particles are characterized by peak intensity with respect to Ca higher than 90\%. These particles can either be detrital and/or biogenic. Ca-rich particles were subdivided into two classes based on their size fraction (Godoi et al., 2009): coccoliths $(<2.5 \mu \mathrm{m})$ and coccolithophore cells (ranging between 2.5 and $10.0 \mu \mathrm{m})$.

\subsection{0. ${ }^{14} \mathrm{C}$ incorporation experiments}

PP or CAL are defined as the potential fixation of DIC into POC or PIC, respectively, under ideal conditions of light, assuming there was no cloud cover. The rate of $C$ fixation was estimated from the incorporation of $\mathrm{H}^{14} \mathrm{CO}_{3}$. Surface seawater from $3 \mathrm{~m}$ depth was collected at dawn in acid-clean carboys, after filtering through a nylon sieve with a mesh size of $200 \mu \mathrm{m}$ to remove zooplankton and then inoculated with $\mathrm{NaH}^{14} \mathrm{CO}_{3}\left(45 \mu \mathrm{Ci} \mathrm{ml}^{-1}\right)$ to reach a final concentration of $20 \mu \mathrm{Ci} \mathrm{L}^{-1}$. For standardization, five samples of $500 \mu \mathrm{l}$ of radioisotopically labelled seawater were placed in scintillation vials to which $500 \mu \mathrm{l} \mathrm{NaOH}(0.1 \mathrm{~N})$ were added; the standards were stored frozen until counting for radioactivity in the laboratory.

Incubations were carried out in sterile $250 \mathrm{ml}$ culture flasks filled with radioisotopically labelled seawater. The bottles were incubated for about $6 \mathrm{~h}$ in a linear incubator reproducing a gradi- 
ent of irradiance ranging between 5 and $400 \mu \mathrm{mol}$ photons $\mathrm{m}^{-2} \mathrm{~s}^{-1}$. During incubation, samples were kept at sea surface temperature (SST) with pumped seawater circulating continuously through the incubator. One flask was wrapped in aluminium foil and another one was poisoned with $5 \%$ sodium azide $\left(3 \mathrm{ml} \mathrm{L}^{-1}\right)$ and both were incubated in the dark for $6 \mathrm{~h}$ to correct for the uptake by abiotic adsorption.

The incorporation was terminated by filtration of $125 \mathrm{ml}$ of each sample at very low vacuum ( $<200$ mbars) on $25 \mathrm{~mm} \mathrm{GF/F}$ glass fiber filters. Duplicate filters were collected for each sample, one filter was left untreated, and the other was acidified (about 2 min on the filtration set) by adding $500 \mu$ of diluted acetic acid $(\sim 0.1 \mathrm{M})$ to eliminate the ${ }^{14} \mathrm{C}$ incorporated as PIC. All filters were rinsed with $25 \mathrm{ml}$ of filtered natural seawater in order to remove the excess $\mathrm{DI}^{14} \mathrm{C}$ and stored frozen in $20 \mathrm{ml}$ scintillation vials until radioactivity measurement in the laboratory. Radioactivity of the standards and the filters was determined in the laboratory by liquid scintillation counting ( $10 \mathrm{ml}$ of ReadySafe scintillation cocktail per vial) and corrected for quenching with an external standard. The acidified samples were measured for radioactivity to quantify the incorporation of ${ }^{14} \mathrm{C}$ in the POC phase (PP). The amount of inorganic ${ }^{14} \mathrm{C}$ incorporated into PIC was obtained by difference between total ${ }^{14} \mathrm{C}$ incorporation and PP. The specific (normalized by Chl-a concentration) $\mathrm{PO}^{14} \mathrm{C}$ and $\mathrm{PI}^{14} \mathrm{C}$ incorporation rates ( $\left.\mu \mathrm{g} \mathrm{C}(\mu \mathrm{g} \mathrm{Chl-a})^{-1} \mathrm{~h}^{-1}\right)$ are presented as a function of PAR irradiance (PPvs.E and CALvs.E, respectively).

\subsection{Computation of PP and CAL rates}

The PP at each depth $(z)\left(\mathrm{PP}_{z}\right.$ in $\left.\mathrm{mg} \mathrm{C} \mathrm{m}{ }^{-3} \mathrm{~d}^{-1}\right)$ was integrated at daily scale according to Eq. (2):

$$
\begin{aligned}
& \mathrm{PP}_{z}=\int_{0}^{t} \operatorname{Chl}-\mathrm{a}_{z} \frac{E_{z, t}}{A E_{z, t}^{2}+B E_{z, t}+C} d t \\
& E_{z, t}=E_{0, t} e^{-K_{d}(\mathrm{PAR}) Z} \\
& E_{0, t}=E_{\max }\left(c_{1}-c_{2} \cos \frac{2 \pi t}{86,400}\right) \\
& c_{1}=1-c_{2} \\
& c_{2}=\frac{1}{1+\cos (\alpha)} \\
& \alpha=\pi\left(1-\frac{L_{d}}{24}\right)
\end{aligned}
$$

In Eq. (2), $A, B$ and $C$ are the parameters determined with the model of Eilers and Peeters (1988) when fitting the PPvs.E curves. Chl-a concentration was calculated for each depth $\left(C h l-a_{z}\right)$ using a linear interpolation between two consecutive depths and this value was assumed constant over the day. The irradiance $\left(E_{z, t}\right)$ at each depth was computed from incoming irradiance $\left(E_{0, t}\right)$ using the diffuse attenuation coefficient of PAR in the water column $\left(K_{d}(\mathrm{PAR})\right)$ determined from the vertical profile of PAR (not shown). Eq. (4) was used to compute the variation of the irradiance with depth and time during the photoperiod. The maximum irradiance at noon $\left(E_{\max }\right)$ and the day-length $\left(L_{d}\right)$ were set to values representative of the studied area during the period of the cruise $\left(1260 \mu \mathrm{mol}\right.$ photon $\mathrm{m}^{-2} \mathrm{~s}^{-1}$ and $13.5 \mathrm{~h}$, respectively).

The daily rate of depth integrated PP $\left(\mathrm{mg} \mathrm{C} \mathrm{m}^{-2} \mathrm{~d}^{-1}\right)$ was computed according to:

$\mathrm{PP}=\int_{0}^{z} \mathrm{PP}_{z} d z$

where $d z$ is the vertical step of integration (in $\mathrm{m}$ ).

Assuming a light dependency of CAL during blooms of coccolithophores, the Eilers and Peeters (1988) equation was also used to fit CALvsE curves and compute CAL at each depth $\left(\mathrm{CAL}_{z}\right.$ in $\mathrm{mg} \mathrm{C} \mathrm{m}^{-3} \mathrm{~d}^{-1}$ ), according to:

$\mathrm{CAL}_{z}=\int_{0}^{t} \mathrm{Chl}-\mathrm{a}_{z} \frac{E_{z, t}}{A^{\prime} E_{z, t}^{2}+B^{\prime} E_{z, t}+C^{\prime}} d t$

where $A^{\prime}, B^{\prime}$ and $C^{\prime}$ are the parameters determined with the model of Eilers and Peeters (1988) when fitting the CALvsE curves.

The daily rate of depth integrated CAL $\left(\mathrm{mg} \mathrm{C} \mathrm{m}^{-2} \mathrm{~d}^{-1}\right)$ was computed according to:

$\mathrm{CAL}=\int_{0}^{z} \mathrm{CAL}_{z} d z$

PP and CAL were integrated on a daily basis over the water column down to $100 \mathrm{~m}$, with a time-step of $20 \mathrm{~s}$ and a vertical resolution of $0.1 \mathrm{~m}$.

\subsection{Bacterial density and production}

Seawater $(5 \mathrm{ml})$ was fixed with $1 \%$ (final concentration) formalin and incubated for $2 \mathrm{~h}$ in the dark, at room temperature with DAPI (4,6-diamidino-2-phenylindole, $0.5 \mu \mathrm{g} \mathrm{ml}^{-1}$ ) in sterile sealed tubes. The sample was filtered through $0.2 \mu \mathrm{m}$ black polycarbonate Nuclepore membrane filters $(25 \mathrm{~mm})$ and quantified for bacterial abundance by oil immersion epifluorescence microscopy (at magnification of $1000 \times$ ).

BPP was estimated from $\left[4,5-{ }^{3} \mathrm{H}\right]$-Leucine $\left(\left[{ }^{3} \mathrm{H}\right]\right.$-Leu $)$ incorporation in surface samples ( $3 \mathrm{~m}$ depth) (Simon and Azam, 1989). A mixture of $\sim 10 \mathrm{ml}$ of $\left[{ }^{3} \mathrm{H}\right]$-Leu (Amersham, $155 \mathrm{Ci} \mathrm{mmol}^{-1}$ ) and cold-Leu was added to achieve final concentrations of $13.1,19.3$, 31.7 and $50.1 \mathrm{nM}$ in $10 \mathrm{ml}$ samples. Triplicates at each concentration were incubated for $1 \mathrm{~h}$ in the dark, at in situ temperature in $15 \mathrm{ml}$ sterile centrifuge tubes. Incubation was stopped by the addition of $269 \mu \mathrm{l}$ of $100 \%$ trichloroacteic acid (TCA) and after $30 \mathrm{~min}$ of protein extraction with TCA, the mixture was filtered on $0.2 \mu \mathrm{m}$, $25 \mathrm{~mm}$ cellulose nitrate filters (Nuclepore). The filters were washed three times with $3 \mathrm{ml}$ of 5\% TCA and stored in scintillation flasks at $-20^{\circ} \mathrm{C}$ until analysis. Radioactivity was determined in the laboratory by liquid scintillation counting (Filter-Count scintillation cocktail). Quenching corrections were made with an external standard. The amount of incorporated Leu was determined and Michaelis-Menten kinetics allowed the computation of the maximal rates $\left(V_{\max }\right)$ and half-saturation constant $\mathrm{km}(\mathrm{nM})$. These rates were further converted into BPP and expressed in $C$ by using an intracellular dilution factor of 2 (Simon and Azam, 1989). A molar fraction of Leu in proteins of 7.3\% and a conversion factor of protein to $C$ production of $86 \%$ with a formula weight of $131.2 \mathrm{~g} \mathrm{~mol}^{-1}$

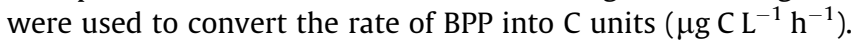

\section{Results}

SST ranged from $12.7^{\circ} \mathrm{C}$ (station 7) to $15.2^{\circ} \mathrm{C}$ during the first leg of the cruise (stations 1, 2, 3, 4, 5, 6, 7, 8 and 10) and increased up to $16.6{ }^{\circ} \mathrm{C}$ during the second leg (stations $12,4 \mathrm{bis}$, 5bis and $7 \mathrm{bis}$ ) (Fig. 2). The mixed layer depth (MLD), defined as the depth of the surface mixed layer i.e. the surface isothermal layer, ranged from $30 \mathrm{~m}$ to $50 \mathrm{~m}$ over the continental shelf, and the thermocline was more pronounced in the northern stations (stations 10 and 8). Deeper mixing with MLD down to $80 \mathrm{~m}$ depth was observed at station 2 (continental shelf) and on the continental slope (stations 3 , 4,6 and 7). The salinity exhibited small variations around 35.6 in the top $100 \mathrm{~m}$, except at station 1 (salinity 35.5 in surface, not shown), where surface water was probably influenced by riverine inputs from the Loire and Gironde (e.g. Kelly-Gerreyn et al., 2006).

DSi concentrations were low in surface waters, ranging from $0.16 \mu \mathrm{mol} \mathrm{L}^{-1}$ (station 10) to $1.79 \mu \mathrm{mol} \mathrm{L}^{-1}$ (station 5) and globally 

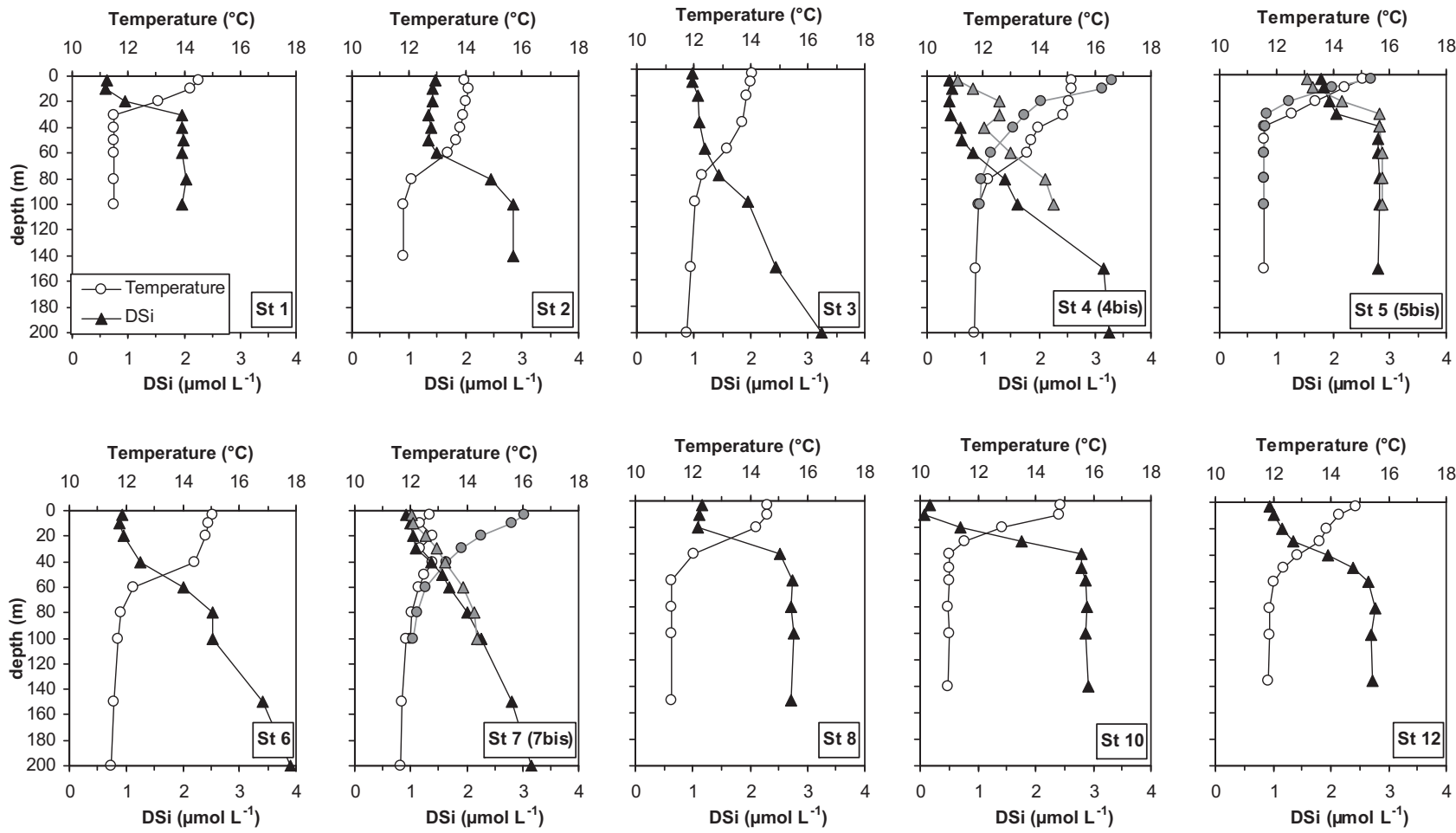

Fig. 2. Vertical profiles of temperature (filled circles, upper axis) and DSi (filled triangles, lower axis) in the northern Bay of Biscay (June 2004). The grey symbols correspond to the vertical profiles at the re-visited stations (station 4bis, 5bis and 7bis).

remained below $2.0 \mu \mathrm{mol} \mathrm{L} \mathrm{L}^{-1}$ in the photic zone (lower limit defined as the depth of $1 \%$ of incoming PAR) (Fig. 2). The increase of DSi concentrations in surface waters at station 4 bis (continental slope), compared to the concentration measured $11 \mathrm{~d}$ before at the same station (station 4), suggests the mixing of the surface waters with deeper waters between the two samplings. This agrees with decrease of $\% \mathrm{O}_{2}$ at $60 \mathrm{~m}$ between the two legs of the cruise at stations 4 and 4bis (Fig. 3). Surface waters were depleted in $\mathrm{PO}_{4}$ $\left(<0.04 \mu \mathrm{mol} \mathrm{L}^{-1}\right)$ down to $20-30 \mathrm{~m}$ at stations $1,10,8$, and 5 , and down to $60-80 \mathrm{~m}$ for stations 2 and 4 (Fig. 4).

Chl-a concentrations ranged from $0.25 \mu \mathrm{g} \mathrm{L}^{-1}$ to $1.50 \mu \mathrm{g} \mathrm{L}^{-1}$ in the top $40 \mathrm{~m}$, and were negligible below $60 \mathrm{~m}$ depth (Fig. 4). The highest Chl-a concentrations generally occurred in sub-surface ( $\sim 20 \mathrm{~m}$ depth), within the photic zone that did not exceed $40 \mathrm{~m}$. When compared to the first leg of the cruise, the Chl-a concentration in surface waters decreased by $50 \%$ in the upper photic zone at the re-visited station $7 \mathrm{bis}$ ( $10 \mathrm{~d}$ apart) or remained $<1.00 \mu \mathrm{g} \mathrm{L} \mathrm{L}^{-1}$ at stations 4 bis and 5 bis.

Surface water $\mathrm{pCO}_{2}$ normalized to $14{ }^{\circ} \mathrm{C}\left(\mathrm{pCO}_{2} @ 14{ }^{\circ} \mathrm{C}\right)$ ranged from $265 \mu \mathrm{atm}$ to $357 \mu \mathrm{atm}$ in the studied area during the first leg (average: $299 \pm 13 \mu \mathrm{atm}$ - Fig. 5). The removal of $\mathrm{CO}_{2}$ by photosynthesis led to surface water under-saturation with respect to atmospheric equilibrium ( $372 \mu \mathrm{atm}$, Mace Head, Ireland) by -15 to $-107 \mu \mathrm{atm}$. Surface water $\mathrm{pCO}_{2} @ 14{ }^{\circ} \mathrm{C}$ increased by c.a. $43 \mu \mathrm{atm}$ (average: $341 \pm 17 \mu \mathrm{atm}$ ) at the re-visited stations 5bis, 4 bis and 7bis, which would indicate either the effect of calcification or the mixing of surface waters with deep waters as a result of a storm on 12-13 June. The lower $\mathrm{pCO}_{2} @ 14{ }^{\circ} \mathrm{C}$ values at the end of Leg 1 and the beginning of Leg 2 were due to the occurrence of an intense phytoplankton bloom in the near-shore waters off Brittany, lowering the $\mathrm{pCO}_{2}$. The upper water column was supersaturated with respect to calcite, with $\Omega_{\text {calcite }}$ values ranging from 3.0 at the bottom of the photic zone to 4.6 in surface waters (Fig. 3). The overall correlation between $\Omega_{\text {calcite }}$ and $\% \mathrm{O}_{2}$ (Fig. 3) indicates that the net organic carbon fixation by photosynthesis was the main driver of the $\Omega_{\text {calcite }}$ vertical patterns.

TA exhibited a non-conservative behaviour with salinity, as shown by the negative off-set between observations and the linear regression of TA vs. salinity established for winter conditions in the area (Fig. 6a). The TA anomalies ( $\Delta \mathrm{TA}$ ) were computed as the difference between the observed TA values and those calculated from salinity using the regression line in Fig. $6 a$. The $\Delta \mathrm{TA}$ values ranged from $+2 \mu \mathrm{mol} \mathrm{kg}-1$ to $-47 \mu \mathrm{mol} \mathrm{kg}{ }^{-1}$, and were more marked at stations 2, 3, 5, 5bis, 6, 7, 7bis and 8 in the HR patch. The observed deficit in TA was probably the result of biogenic $\mathrm{CaCO}_{3}$ precipitation in surface waters (Eq. (1)). The correlation between $\triangle \mathrm{TA}$ and $\mathrm{pCO}_{2} @ 14{ }^{\circ} \mathrm{C}$ in surface waters (Fig. 6b) is consistent with the production of dissolved $\mathrm{CO}_{2}$ during biogenic $\mathrm{CaCO}_{3}$ precipitation (Eq. (1)). Data obtained during the second leg of the cruise stand above from the linear regression between $\mathrm{pCO}_{2} @ 14^{\circ} \mathrm{C}$ and $\Delta \mathrm{TA}$ established from the data obtained during the first leg of the cruise. The input of TA and $\mathrm{pCO}_{2}$ from depth to surface due to vertical mixing by a storm event between the two legs of the cruise modified the relationship between these two quantities when compared to the first leg (increase of $\mathrm{pCO}_{2} @ 14{ }^{\circ} \mathrm{C}$ and TA anamolies (i.e. increase of TA)).

TEP-C concentrations ranged between $15.3 \mu \mathrm{g} \mathrm{C} \mathrm{L}^{-1}$ (station 10 at $30 \mathrm{~m}$ ) and $75.2 \mu \mathrm{g} \mathrm{C} \mathrm{L}^{-1}$ (station 7bis at $10 \mathrm{~m}$ ) (Fig. 7). Average TEP-C values decreased from the top $40 \mathrm{~m}$ layer $(28.0 \pm 2.1$ $\mu \mathrm{g} \mathrm{C} \mathrm{L}-1, n=56)$ to the deeper waters (18.2 $\left.\pm 0.7 \mu \mathrm{g} \mathrm{C} \mathrm{L}^{-1}, n=55\right)$, where TEP-C concentrations were relatively constant below $150 \mathrm{~m}$, down to $1000 \mathrm{~m}\left(16.3 \mu \mathrm{g} \mathrm{C} \mathrm{L}^{-1}\right.$ at station 7 , data not shown). Over the continental shelf, TEP-C concentrations in surface waters as high as $65.5 \mu \mathrm{g} \mathrm{C} \mathrm{L}{ }^{-1}$ and $69.9 \mu \mathrm{g} \mathrm{C} \mathrm{L}^{-1}$ were observed at stations 2 and 8 , respectively. At station 5 , low concentrations of TEP-C were observed $\left(<25 \mu \mathrm{g} \mathrm{C} \mathrm{L}^{-1}\right)$, even after re-occupation of the station ( $9 \mathrm{~d}$ apart). However, the concentration of TEP-C in surface waters over the continental slope increased between the 2 legs 

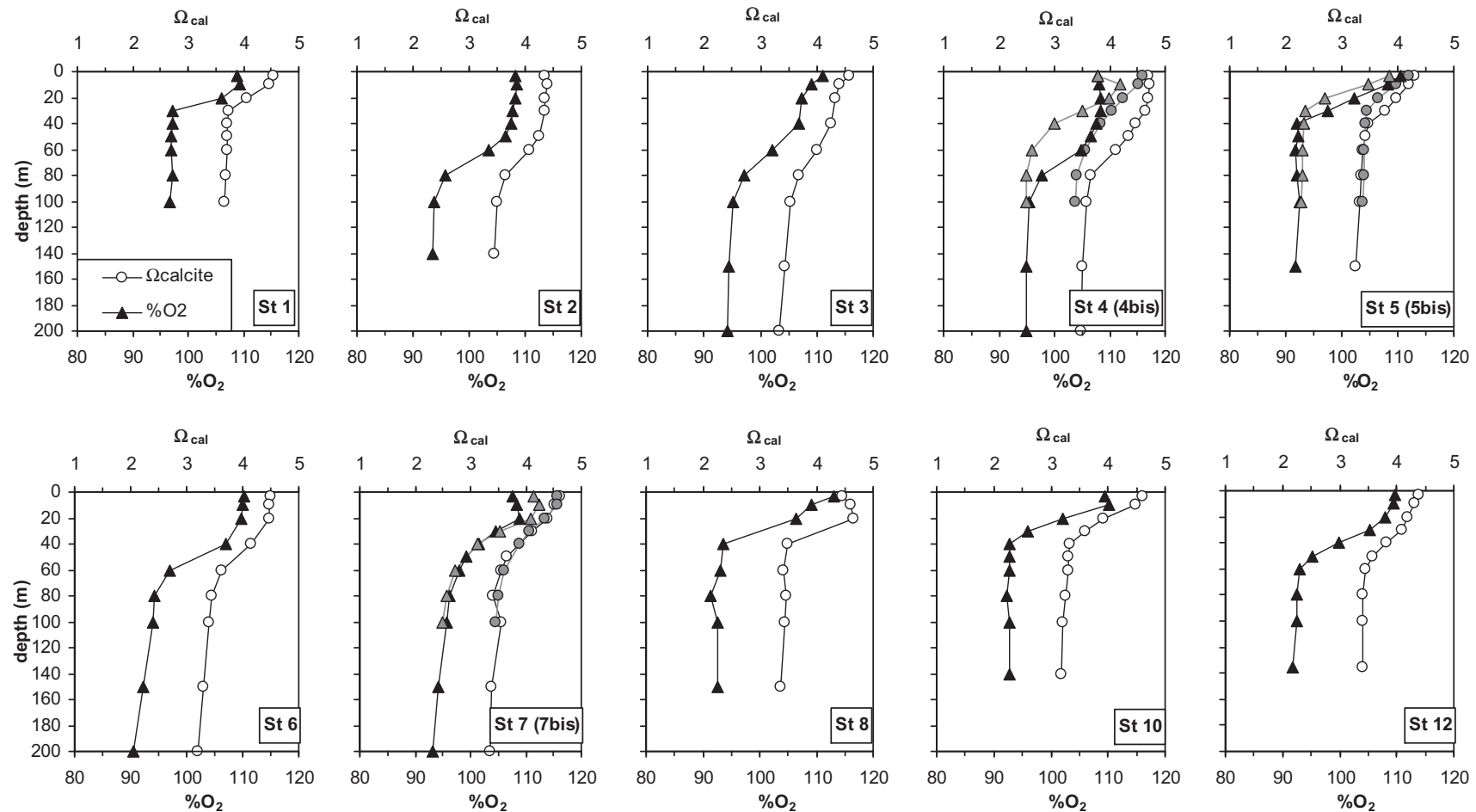

Fig. 3. Vertical profiles of $\Omega_{\text {cal }}$ (filled circles, upper axis) and $\% \mathrm{O}_{2}$ (filled triangles, lower axis) in the northern Bay of Biscay (June 2004). The grey symbols correspond to the profiles of the two parameters at the re-visited stations (station 4 bis, 5 bis and $7 \mathrm{bis}$ ).
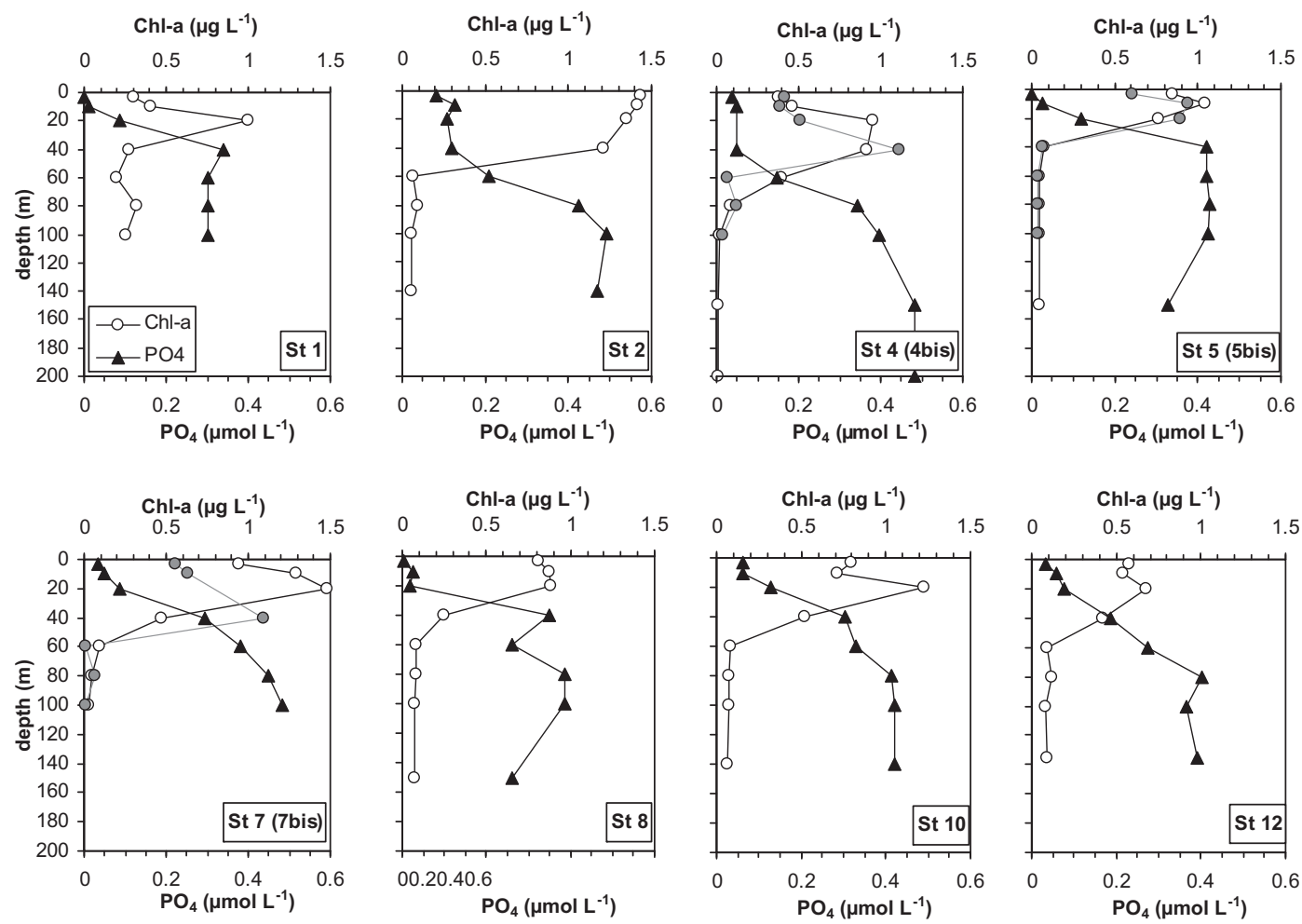

Fig. 4. Vertical profiles of Chl-a (filled circles, upper axis) and $\mathrm{PO}_{4}$ (filled triangles, lower axis) in the northern Bay of Biscay (June 2004). The grey symbols correspond to the vertical profiles at the re-visited stations (station 4 bis, 5bis and 7bis). These parameters were not sampled at stations 3 and 6 , and $\mathrm{PO}_{4}$ was not sampled at the re-visited stations 4 bis, 5 bis and 7 bis.

of the cruise by two- and four-fold at stations 4 bis and $7 \mathrm{bis}$, respectively.

The POC concentration in the photic zone ranged between $92.4 \mu \mathrm{g} \mathrm{CL}^{-1}$ (station 1) and $186.0 \mu \mathrm{g} \mathrm{C} \mathrm{L}^{-1}$ (station 10) and de- creased to values $<48 \mu \mathrm{g} \mathrm{C} \mathrm{L}{ }^{-1}$ below $60 \mathrm{~m}$ depth (Fig. 8). The highest PIC concentrations were generally observed in surface waters, occasionally at depths below $40 \mathrm{~m}$ (e.g. station 4 ; Fig. 8). The highest PIC concentrations were observed at station 5 , over the 


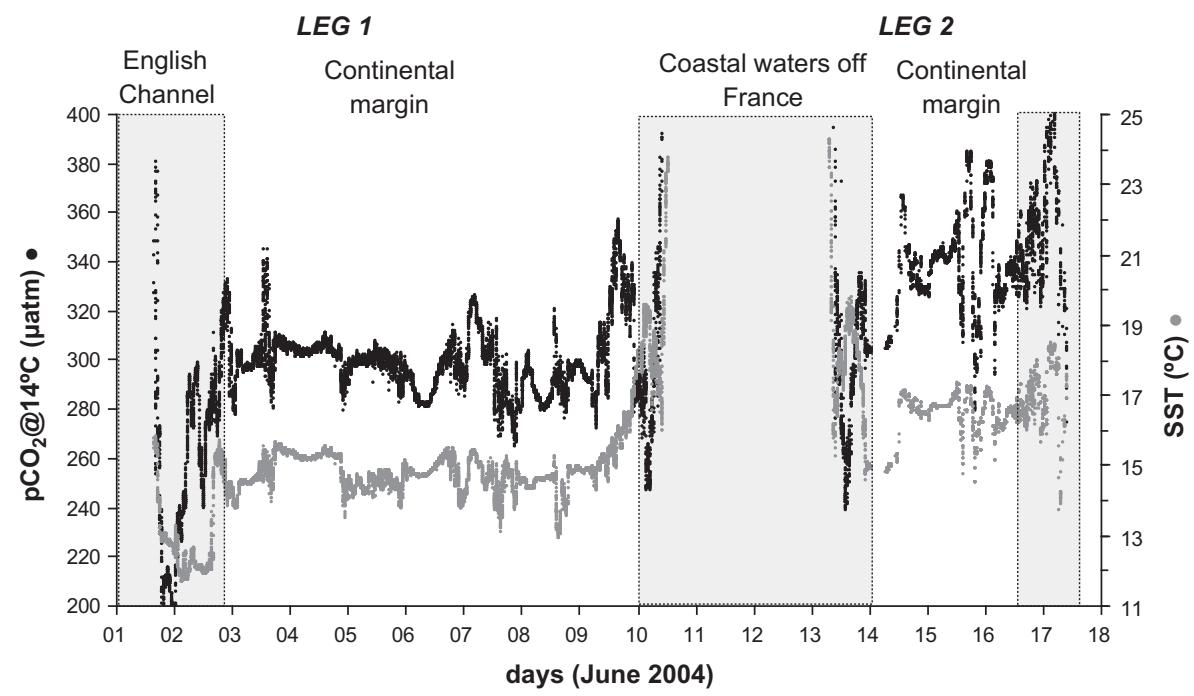

Fig. 5. Underway $\mathrm{pCO}_{2} @ 14{ }^{\circ} \mathrm{C}(\mu \mathrm{atm})$ and SST $\left({ }^{\circ} \mathrm{C}\right)$ during the cruise in the northern Bay of Biscay (June 2004).

continental shelf ( $98.4 \mu \mathrm{g} \mathrm{C} \mathrm{L} \mathrm{L}^{-1}$ in the top $20 \mathrm{~m}$ ). In surface waters, PIC concentrations were generally lower than $48 \mu \mathrm{g} \mathrm{C} \mathrm{L^{-1 }}$ and decreased below $12 \mu \mathrm{g} \mathrm{C} \mathrm{L}^{-1}$ at depth. The PIC:POC molar ratio in the photic zone ranged between 0.2 and 0.3 at most stations (not shown), and was highest at station 5 (0.9). Integrated PIC in the top $150 \mathrm{~m}$ ranged between $0.636 \mathrm{~g} \mathrm{C} \mathrm{m}^{-2}$ and $4.130 \mathrm{~g} \mathrm{C} \mathrm{m}^{-2}$ at stations 12 and 5 , respectively (Table 1 ). The highest integrated PIC values $\left(>1.6 \mathrm{~g} \mathrm{C} \mathrm{m}^{-2}\right.$ ) were observed over the continental shelf at stations 10 and 2 .

Coccosphere abundances in surface waters were lower on the continental slope $\left(<2 \times 10^{6}\right.$ cells $\mathrm{L}^{-1}$ at stations 4 and 7$)$ than on the continental shelf $\left(\sim 2 \times 10^{6}\right.$ cells $\mathrm{L}^{-1}$ at station 2$)$ (Fig. 9). Coccosphere abundances higher than $4 \times 10^{6}$ cells $\mathrm{L}^{-1}$ were observed in the upper photic layer at station 8 and exceeded $8 \times 10^{6}$ cells L $^{-1}$ at station 5. Low coccosphere abundances were observed at depths $>40 \mathrm{~m}\left(<10^{6}\right.$ cells $\left.\mathrm{L}^{-1}\right)$. The abundance of detached coccoliths exceeded $10^{7}$ liths $\mathrm{L}^{-1}$ over the continental shelf, with the highest values at station $5\left(53 \times 10^{6}\right.$ liths $\left.\mathrm{L}^{-1}\right)$ and the lowest values on the continental slope at station $4\left(<2 \times 10^{6}\right.$ liths $\left.\mathrm{L}^{-1}\right)$. The concentration of detached coccoliths was approximately five times higher than the concentration of coccospheres. A secondary peak of detached coccoliths was observed at $40 \mathrm{~m}$ depth at stations 2 and 4 , decreasing rapidly with depth.

The PPvs.E and CALvs.E curves were used to characterize the specific productivity in terms of organic and inorganic C, respectively, of the phytoplankton assemblages in response to irradiance (PAR). The saturating PP ranged between $2.0 \mu \mathrm{g} \mathrm{C}(\mu \mathrm{g} \mathrm{Chl-a})^{-1} \mathrm{~h}^{-1}$ and $5.4 \mu \mathrm{gC}(\mu \mathrm{g} \mathrm{Chl}-\mathrm{a})^{-1} \mathrm{~h}^{-1}$, and were obtained at irradiances above $200 \mu \mathrm{mol}$ photons $\mathrm{m}^{-2} \mathrm{~s}^{-1}$ (Fig. 10). The lowest saturating PP were determined at stations $1,2,5$ and 7 . No relationship was found between specific (i.e. normalized by Chl-a concentration) PP and CAL during the cruise, which suggests mixed phytoplankton assemblages where the coccolithophore $E$. huxleyi was abundant enough to produce HR and induce detectable CAL but not necessarily dominant species in the phytoplankton assemblage. The variable composition of the phytoplankton assemblages (E. huxleyi vs. others) may have led to different responses of PP and CAL to irradiance from one station to another. As a consequence, the PPvs.E and CALvs.E curves typical of phytoplankton communities dominated by E. huxleyi described by Holligan et al. (1993a) were not systematically observed during our study. The specific CAL rates were very low at saturating irradiance (below $1 \mu \mathrm{g} \mathrm{C}$ $(\mu \mathrm{g} \mathrm{Chl}-\mathrm{a})^{-1} \mathrm{~h}^{-1}$ ) except at station 5 where CAL was similar to PP. At stations 5 and 2 (saturating CAL close to $2.0 \mu \mathrm{g} \mathrm{C} \mathrm{(} \mu \mathrm{g}$ Chl- a $)^{-1} h^{-1}$ ), the initial increase of CAL with irradiance was not linear, as observed for PP. This could be an artefact of the determination of CAL by ${ }^{14} \mathrm{C}$ incorporation. The time required for the production of one coccolith by E. huxleyi is approximately $2-3 \mathrm{~h}$ under optimal conditions of light (Linschooten et al., 1991; Fernández et al., 1993). The time required for the production of radioisotopically labelled calcite in sub-optimal light conditions (low irradiance) is most probably longer than $2-3 \mathrm{~h}$, hence comparable to the relatively short incubation time $(6 \mathrm{~h})$, possibly leading to an underestimation of CAL rates as measured by ${ }^{14} \mathrm{C}$ incorporation.

Maximum $\mathrm{PP}_{z}$ rates above $30.0 \mathrm{mg} \mathrm{C} \mathrm{m}^{-3} \mathrm{~d}^{-1}$ and up to $37.3 \mathrm{mg} \mathrm{C} \mathrm{m}^{-3} \mathrm{~d}^{-1}$ were determined in the photic layer at stations 2, 5bis, 7bis, 8,10 and 12 with maximal $\mathrm{PP}_{z}$ values in sub-surface waters between $2 \mathrm{~m}$ and $10 \mathrm{~m}$ (Fig. 11). Due to the lower Chl-a concentrations and the attenuation of light with depth, the $\mathrm{PP}_{z}$ strongly decreased below $40 \mathrm{~m}$. The highest $\mathrm{CAL}_{z}$ rates (12.3 $\mathrm{mg} \mathrm{C} \mathrm{m}^{-3} \mathrm{~d}^{-1}$ ) were observed at station 2, located within the $\mathrm{HR}$ patch. The $\mathrm{CAL}_{z}$ rates were lower than $\mathrm{PP}_{z}$, $<5.0 \mathrm{mg} \mathrm{C} \mathrm{m}{ }^{-3} \mathrm{~d}^{-1}$, and showed maximum values at same the depths as maximum $\mathrm{PP}_{z}$ values. The high $\mathrm{CAL}_{z}$ rate determined in surface of station $12\left(58.5 \mathrm{mg} \mathrm{C} \mathrm{m}^{-3} \mathrm{~d}^{-1}\right)$ was likely an artefact in the computation of the integration since the value integrated in the top $10 \mathrm{~m}$ corresponded to c.a. $50 \%$ of the value integrated in the whole water column $\left(124.0 \mathrm{mg} \mathrm{C} \mathrm{m}^{-2} \mathrm{~d}^{-1}\right.$; Table 1$)$. It is reasonable to consider at this station an integrated CAL rate lower by $50 \%$ (i.e. $62 \mathrm{mg} \mathrm{C} \mathrm{m}^{-2} \mathrm{~d}^{-1}$ ).

Integrated CAL daily rates ranged from 14 to $141 \mathrm{mg} \mathrm{C} \mathrm{m}^{-2} \mathrm{~d}^{-1}$ at stations 10 and 2, respectively. Between the two legs of the cruise, a two-fold increase of CAL rates was observed between station 5 ( $47 \mathrm{mg} \mathrm{C} \mathrm{m}^{-2} \mathrm{~d}^{-1}$ ) and station 5bis (98 $\left.\mathrm{mg} \mathrm{C} \mathrm{m}^{-2} \mathrm{~d}^{-1}\right)$. A decrease by more than $50 \%$ was observed after $10 \mathrm{~d}$, at the re-visited stations $7 \mathrm{bis}$ and $4 \mathrm{bis}$, located over the slope. The mean CAL during the cruise was $60 \pm 37 \mathrm{mg} \mathrm{C} \mathrm{m}^{-2} \mathrm{~d}^{-1}(n=11)$.

Integrated PP daily rates ranged from $215 \mathrm{mg} \mathrm{C} \mathrm{m}^{-2} \mathrm{~d}^{-1}$ (station 5) to $681 \mathrm{mg} \mathrm{C} \mathrm{m}^{-2} \mathrm{~d}^{-1}$ (station 5bis) (Table 1). The depth integrated Chl-a concentrations ranged from 23.1 to

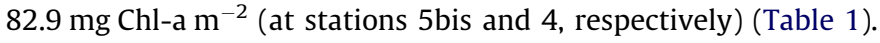
No statistical difference was found between integrated PP on the continental shelf and over the continental slope $(p>0.05)$. The ratio of integrated CAL to integrated PP (CAL:PP ratio) ranged between 0.03 (station 10) and 0.31 (station 2). The lowest CAL:PP ratio values were observed at the stations 7bis, 4 and 4 bis (over the continental slope), and at stations 10 and 12 (on the continental shelf). 

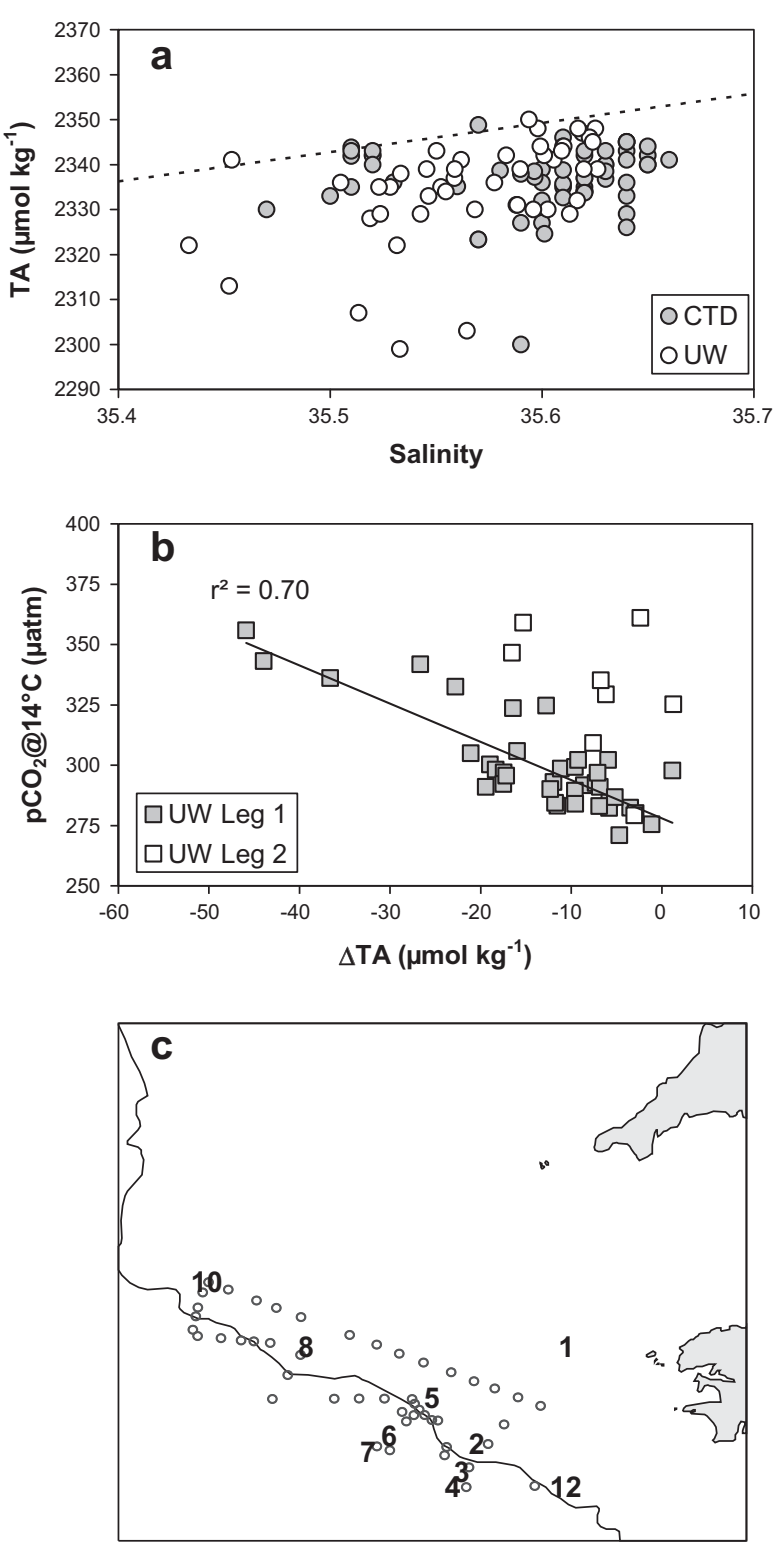

Fig. 6. (a) $\mathrm{TA}\left(\mu \mathrm{mol} \mathrm{kg}{ }^{-1}\right)$ in the upper $40 \mathrm{~m}$ as a function of salinity in the northern Bay of Biscay (June 2004) from CTD casts and additional samples at $3 \mathrm{~m}$ depth (underway (UW) sampling from seawater supply). The linear relationship of TA vs. salinity (dotted line; $\mathrm{TA}=39+64.9 \times$ salinity) is based on data obtained in northern Bay of Biscay during the OMEX-II project during periods of low biological activity (winter data), when calcification can be safely assumed negligible (A.V. Borges, unpubl.). (b) Relationship between $\mathrm{pCO}_{2} @ 14{ }^{\circ} \mathrm{C}(\mu \mathrm{atm})$ and the $\Delta \mathrm{TA}\left(\mu \mathrm{mol} \mathrm{kg}{ }^{-1}\right)$ in surface waters (computed as the difference between observations and the values predicted from the linear regression) for the first and second leg of the cruise. Data for salinities <35.4 were excluded because influenced by river runoff and outside the range of salinities for which the TA-salinity relationship was established. (c) Map showing position of the CTD stations and underway samplings.

At station 1 , bacterial abundance was low $\left(0.5 \times 10^{9}\right.$ cells L $\left.^{-1}\right)$ and remained relatively constant with depth (Fig. 7). At the continental shelf stations $(10,8,5,2$ and 12), bacterial abundances were higher in the upper layer of the water column, with abundances $>1 \times 10^{9}$ cells L $^{-1}$ in surface waters of all stations and $>3 \times 10^{9}$ cells $\mathrm{L}^{-1}$ at station 5 . Bacterial abundance was lower below $60 \mathrm{~m}$, ranging between $0.5 \times 10^{9}$ cells L $^{-1}$ and $1 \times$ $10^{9}$ cells $\mathrm{L}^{-1}$. A decrease of bacterial abundance was observed in surface waters at the re-visited station 5bis compared to station 5 , while it exhibited similar values at station 4 bis compared to station 4 and at station 7 bis compared to station 7 . Visual check under epifluorescence suggests that the bacteria were aggregated on suspended materials in the surface waters and an "aggregate-type" statistical repartition of bacteria on the filters was confirmed by variance analysis of the random counts per filter.

BPP rates in surface waters ranged from $0.26 \mu \mathrm{g} \mathrm{C} \mathrm{L}^{-1} \mathrm{~h}^{-1}$ to $0.71 \mu \mathrm{g} \mathrm{C} \mathrm{L}^{-1} \mathrm{~h}^{-1}$ for stations 4 bis and 10 , respectively, and averaged $0.46 \pm 0.15 \mu \mathrm{g} \mathrm{CL}^{-1} \mathrm{~h}^{-1}(n=11)$ over the entire cruise (Table 1 ). On average, BPP rates were lower at the three re-visited stations compared to the first leg of the cruise (between 0.26 and

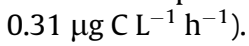

\section{Discussion}

\subsection{Environmental settings during the coccolithophore bloom}

The northern Bay of Biscay continental margin is characterized by complex hydrodynamics due to the steep bathymetric change at continental slope separating the deep abyssal plain $(>3000 \mathrm{~m})$ from the shallow continental shelf $(<200 \mathrm{~m})$. In the study area, internal wave breaking is at the origin of seasonal changes in the direction and the intensity of surface residual currents and cause at the shelf break enhanced vertical mixing of deep waters with surface waters (Huthnance et al., 2001). The vertical mixing at the shelf break leads to discontinuous inputs of nutrients to surface waters that sustain high primary production (Joint et al., 2001). Along the shelf break primary production is higher in the southern area (La Chapelle Bank) than further north (Goban Spur) due to a steeper continental slope that leads to stronger vertical mixing by internal tides (Wollast and Chou, 2001a,b). In June 2004, cooling of surface waters was observed at the continental shelf break on the composite image of remotely sensed SST (Fig. 1b). The vertical profiles of temperatures over the continental shelf (stations 10,8 , 5,2 and 12) showed stronger thermal stratification with vertical gradients of $3-4{ }^{\circ} \mathrm{C}$ across the thermocline and higher SST values (ranging between $14.0^{\circ} \mathrm{C}$ and $15.0^{\circ} \mathrm{C}$ ) than over the continental slope (Fig. 2). The coldest station was station 7 , where SST $\left(12.7^{\circ} \mathrm{C}\right)$ was close to the value recorded at $100 \mathrm{~m}$ depth. Such a distribution of SST and vertical temperature gradients is related to enhanced vertical mixing over the continental slope. No haline stratification was observed, except at station 1 due to the inputs from the Loire and Gironde rivers (e.g. Kelly-Gerreyn et al., 2006).

The cold water patches were constrained on a narrow band along the shelf break and were associated with higher remotely sensed Chl-a concentrations (Fig. 1c). The patch of higher Chl-a extended over the continental shelf and values declined in the direction of station 1. The in situ Chl-a measurements agreed with the patterns of the remotely sensed data, with higher concentrations in surface waters at station 2 and lower concentrations at adjacent stations, but in situ concentrations rarely exceeded $1.0 \mu \mathrm{g} \mathrm{L}^{-1}$ (Fig. 4). The vertical distribution of Chl-a showed a consistent pattern at all stations with maxima at the surface $(3 \mathrm{~m})$ or sub-surface $(20 \mathrm{~m})$, and very low values below $60 \mathrm{~m}$ depth.

Extensive coccolithophore blooms, characterized by HR patches with high concentrations of suspended calcite, have been studied in the north-eastern Atlantic Ocean (Fernández et al., 1993; Holligan et al., 1993a; Robertson et al., 1994), western Atlantic Ocean (Balch et al., 1991; Brown and Yoder, 1994) and in the North Sea (Holligan et al., 1993b; Marañón and González, 1997; Head et al., 1998; Rees et al., 2002) (Table 2). Across the Azores front (North Atlantic Ocean), E. huxleyi abundances in surface waters ranged be-

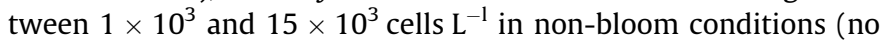
higher reflectance observed) (Schiebel et al., 2002). During bloom peak conditions, E. huxleyi cell abundances $>1-5 \times 10^{6}$ cells L ${ }^{-1}$ were observed in the north-eastern Atlantic Ocean (Holligan et al., 1993a) and up to $8 \times 10^{6}$ cells L $^{-1}$ off the Shetland Islands (Head et al., 1998). During our study, the patch of HR, more intense 

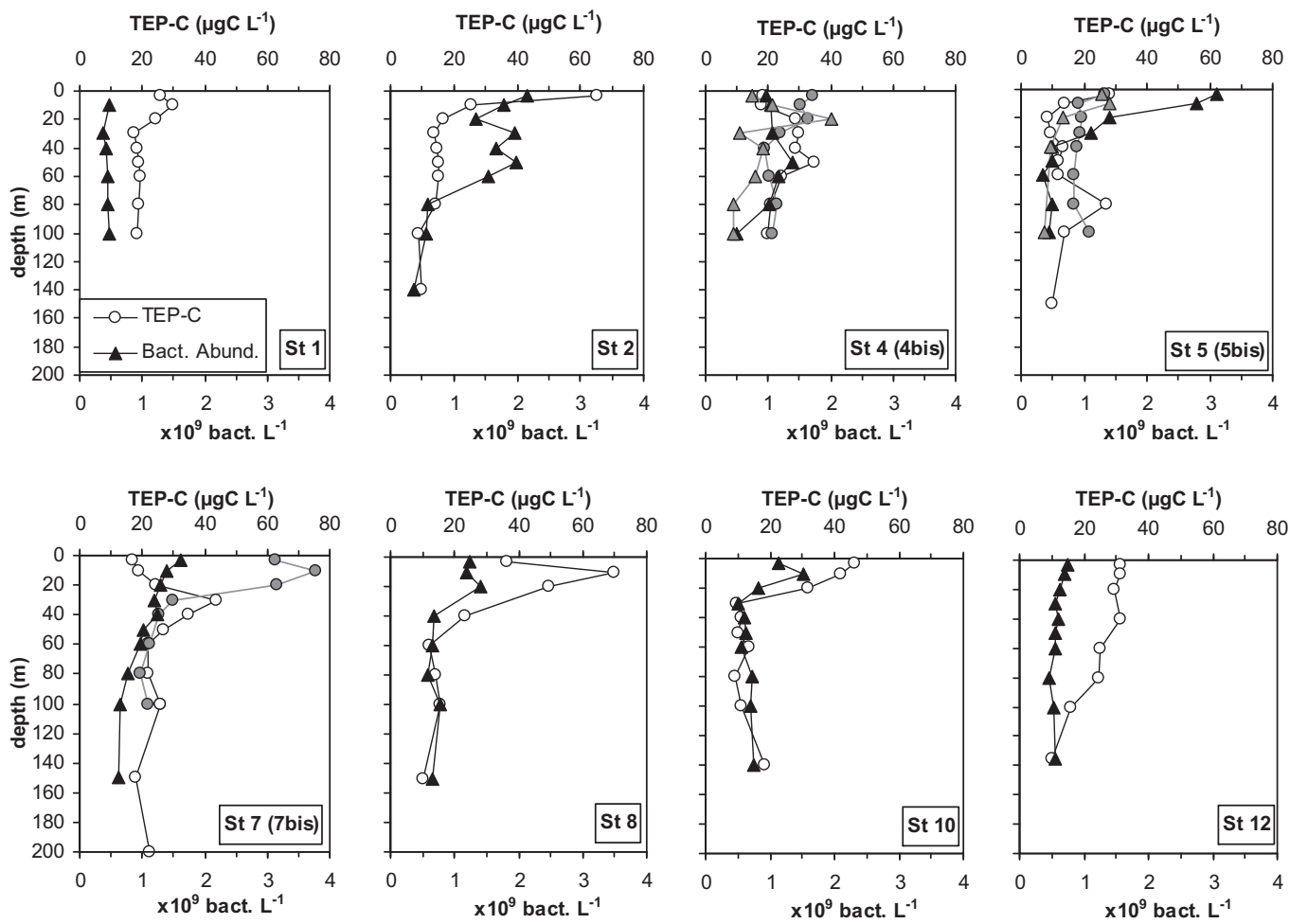

Fig. 7. Vertical profiles of TEP-C (filled circles; upper axis) and bacterial density (filled triangles; lower axis) in the northern Bay of Biscay (June 2004). The grey symbols correspond to the vertical profiles at the re-visited stations (4bis, $5 \mathrm{bis}$ and $7 \mathrm{bis}$ ). These parameters were not sampled at stations 3 and 6 .
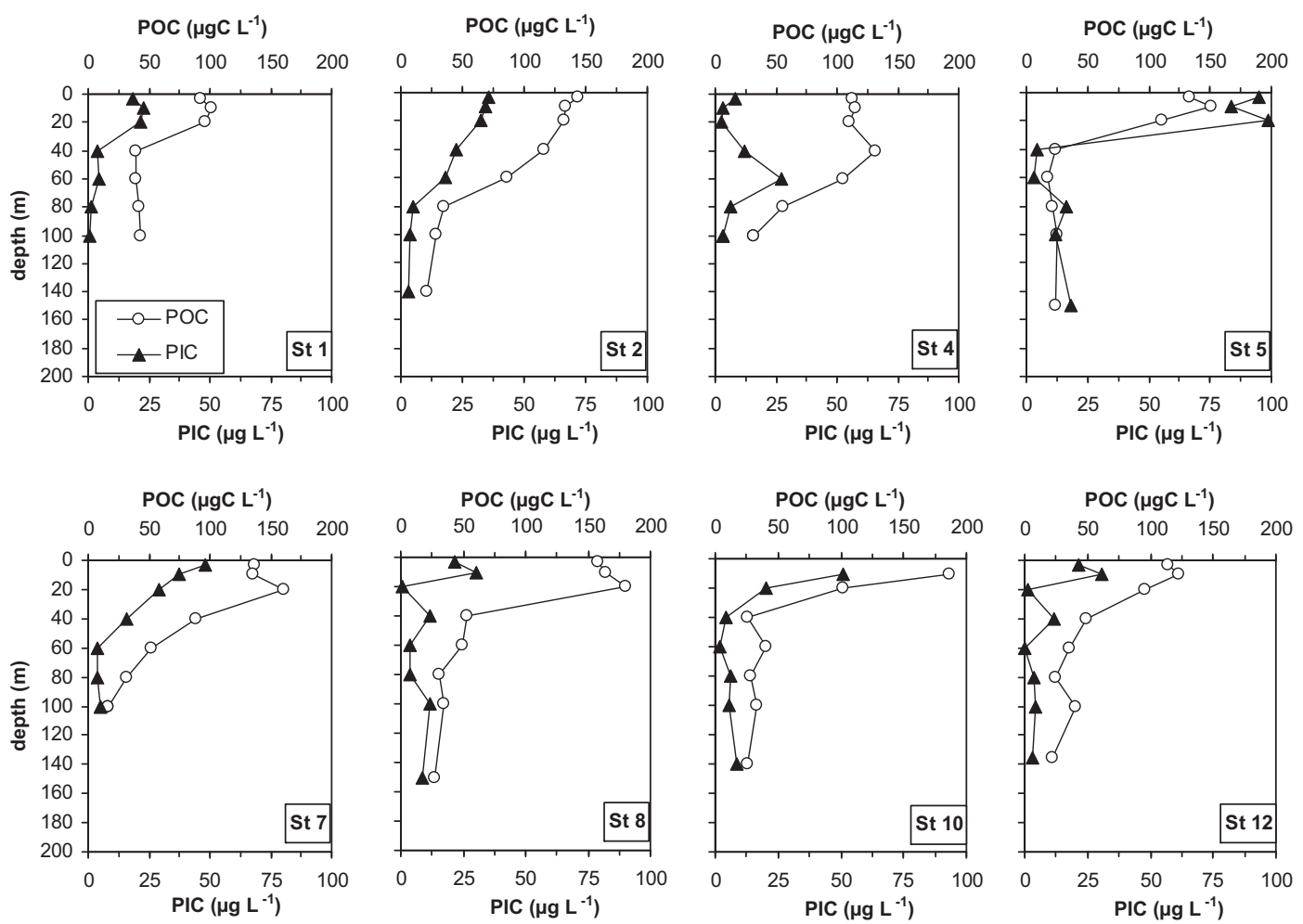

Fig. 8. Vertical profiles of POC (filled circles, upper axis) and PIC (filled triangles, lower axis) concentrations in the northern Bay of Biscay (June 2004). These parameters were not sampled at stations 3, 6, 4bis, 5bis and 7bis.

around station 5, stretched along the slope from station 2 to station 10 and spanned over the continental shelf, from the continental margin up to station 1 on 13 June 2004 (Fig. 1d). A filament of
HR extended southward at stations 6 and 7 and low or no reflectance was observed at stations 4 and 12 . Coccolithophore abundances $>8 \times 10^{6}$ cells $\mathrm{L}^{-1}$ occurred in the HR patch, at station 5 
Table 1

Sea surface temperature (SST), downwelling diffuse irradiance attenuation coefficient for PAR ( $K_{d}(\mathrm{PAR})$ ), the integrated Chlorophyll-a, integrated primary production (PP) and calcification (CAL) rates $\left(\mathrm{g} \mathrm{C} \mathrm{m}^{-2} \mathrm{~d}^{-1}\right)$, CAL:PP ratio, integrated PIC concentration $\left(\mathrm{g} \mathrm{C} \mathrm{m}^{-2}\right.$ ) over the top $150 \mathrm{~m}$, PIC accumulation time (computed as the ratio between standing

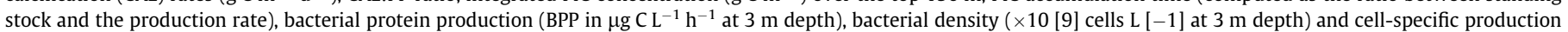
( $f g \mathrm{Ch}^{-1}$ at $3 \mathrm{~m}$ depth) in northern Bay of Biscay, in June 2004. The asterisk indicates stations over the continental shelf, other stations are over the continental slope.

\begin{tabular}{|c|c|c|c|c|c|c|c|c|c|c|c|c|c|c|}
\hline \multirow[t]{2}{*}{ Station } & \multirow[t]{2}{*}{ Date } & \multirow{2}{*}{$\begin{array}{l}\text { Lat. } \\
\left({ }^{\circ} \mathrm{N}\right)\end{array}$} & \multirow{2}{*}{$\begin{array}{l}\text { Long. } \\
\left({ }^{\circ} \mathrm{W}\right)\end{array}$} & \multirow{2}{*}{$\begin{array}{l}\text { SST } \\
\left({ }^{\circ} \mathrm{C}\right)\end{array}$} & \multirow{2}{*}{$\begin{array}{l}K_{d}(\mathrm{PAR}) \\
\left(\mathrm{m}^{-1}\right)\end{array}$} & \multirow{2}{*}{$\begin{array}{l}\text { Integrated } \\
\text { Chl-a } \\
\left(\mathrm{mg} \mathrm{Chl-a} \mathrm{m}{ }^{-2}\right)\end{array}$} & \multirow{2}{*}{$\frac{P P}{(m g C}$} & \multirow{2}{*}{$\frac{\mathrm{CAL}}{\left.\mathrm{m}^{-2} \mathrm{~d}^{-1}\right)}$} & \multirow{2}{*}{\multicolumn{2}{|c|}{$\begin{aligned} \text { CAL:PP } & \text { Integrated } \\
& \text { PIC } \\
& \left(\mathrm{mg} \mathrm{C} \mathrm{m}^{-2}\right)\end{aligned}$}} & \multirow{2}{*}{$\begin{array}{l}\text { PIC } \\
\text { accumulation } \\
\text { time } \\
\text { (d) }\end{array}$} & \multirow{2}{*}{$\begin{array}{l}\text { BPP } \\
\left(\mu g \mathrm{C} \mathrm{L}^{-1} \mathrm{~h}^{-1}\right)\end{array}$} & \multirow{2}{*}{$\begin{array}{l}\text { Bacterial } \\
\text { abundance } \\
(\times 10[9] \text { cells } L[-1])\end{array}$} & \multirow{2}{*}{ 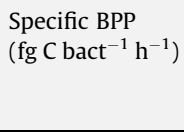 } \\
\hline & & & & & & & & & & & & & & \\
\hline $1^{*}$ & 3-June & 48.500 & 6.000 & 14.5 & 0.17 & 25.5 & 308 & 69 & 0.22 & 1046 & 15.2 & 0.64 & 0.48 & 1.33 \\
\hline $2^{*}$ & 5-June & 47.750 & 7.000 & 14.0 & 0.20 & 66.2 & 449 & 141 & 0.31 & 2019 & 14.3 & 0.37 & 2.17 & 0.17 \\
\hline 4 & 4-June & 47.533 & 7.267 & 15.2 & 0.14 & 82.9 & 411 & 45 & 0.11 & 1095 & 24.3 & 0.37 & 0.97 & 0.38 \\
\hline 4bis & 15-June & 47.417 & 7.267 & 16.6 & 0.14 & 41.3 & 357 & 16 & 0.04 & - & - & 0.26 & 3.11 & 0.08 \\
\hline $5^{*}$ & 7-June & 48.100 & 7.500 & 15.0 & 0.30 & 25.9 & 215 & 47 & 0.22 & 4130 & 87.9 & 0.54 & 1.61 & 0.34 \\
\hline 5 bis $^{*}$ & 16-June & 48.100 & 7.500 & 15.4 & 0.21 & 23.1 & 681 & 98 & 0.14 & - & - & 0.31 & 1.25 & 0.25 \\
\hline 7 & 6-June & 47.683 & 8.208 & 12.7 & 0.17 & 55.0 & 276 & 76 & 0.28 & 1551 & 20.4 & 0.51 & 1.14 & 0.45 \\
\hline 7bis & 16-June & 47.683 & 8.208 & 16.1 & 0.18 & 45.6 & 383 & 25 & 0.07 & - & - & 0.33 & 0.75 & 0.44 \\
\hline $8^{*}$ & 8-June & 48.500 & 8.900 & 14.6 & 0.15 & 36.4 & 437 & 62 & 0.14 & 1410 & 22.7 & 0.60 & 0.74 & 0.81 \\
\hline $10^{*}$ & 9-Jun & 49.000 & 10.000 & 14.9 & 0.15 & 45.7 & 511 & 14 & 0.03 & 1635 & 116.8 & 0.71 & 1.29 & 0.55 \\
\hline $12^{*}$ & 14-June & 47.417 & 6.000 & 14.9 & 0.13 & 27.9 & 670 & 62 & 0.09 & 636 & 5.1 & 0.45 & 2.12 & 0.21 \\
\hline
\end{tabular}
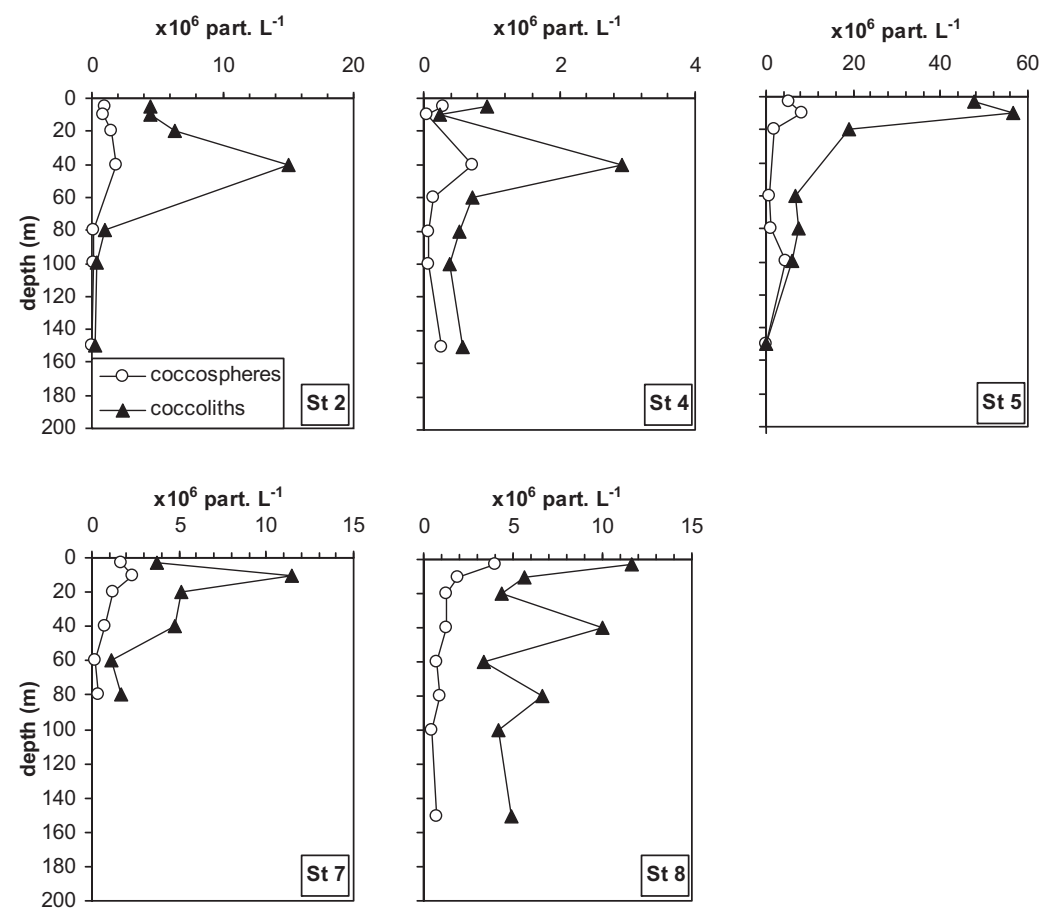

Fig. 9. Vertical profiles of the coccolith (dashed line) and coccosphere (thick line) abundances in the northern Bay of Biscay (June 2004). Stations 1, 10, 12 and the re-visited stations were not analyzed for these parameters.

(sub-surface samples), where a PIC concentration $\sim 90 \mu \mathrm{g} \mathrm{C} \mathrm{L}$ was measured in surface waters, which was approximately twice the values at stations $10,8,2$ and 7 , and more than three times the values at stations 4,12 and 1 (Fig. 8). The lowest coccolithophore cell density $\left(0.3 \times 10^{6}\right.$ cells $\left.\mathrm{L}^{-1}\right)$ was observed at station 4 , located outside the HR patch (Fig. 9). The maximum density of coccoliths exceeded $10 \times 10^{6}$ liths $\mathrm{L}^{-1}$ at stations 2,7 and 8 and reached $53 \times 10^{6}$ liths $\mathrm{L}^{-1}$ at station 5 . These values are one order of magnitude lower than those reported by van der Wal et al. (1995) in the North Sea and by Balch et al. (1991) in the Gulf of Maine but remain within the range of the values reported by Holligan et al. (1983) in the north-eastern Atlantic Ocean and by Head et al. (1998) in the North Sea (Table 2). A maximum suspended coccoliths:coccosphere ratio of 10 was observed at station 5 , which is close to the values of 20-40 reported by Holligan et al. (1983) at the shelf break of the Bay of Biscay. However, this value is one order of magnitude lower than values $>200$ reported by Balch et al.
(1991) in the Gulf of Maine and by Garcia-Soto et al. (1995) in the Western English Channel, who presumably observed a different stage of the bloom.

Vertical profiles of nutrients indicate $\mathrm{PO}_{4}$ depletion in surface waters and levels of DSi $\left(<2 \mu \mathrm{mol} \mathrm{L}^{-1}\right)$ limiting for diatom growth (Egge and Aksnes, 1992) (Figs. 2 and 4). In these conditions, coccolithophores, such as the bloom-forming E. huxleyi may be more competitive and thus dominate the phytoplankton community. The SEM observations (not shown) revealed that coccolithophores were present, mainly E. huxleyi and other species like Gephyrocapsa oceanica at lower densities, as well as less abundant and probably old population of diatoms. In mesocosms, the transition from a diatom-dominated to a coccolithophore-dominated assemblage led to a reduction of biomass and of productivity (Marañon et al., 1996). The patterns of remotely sensed variables (Fig. 1b-d) and PP and CAL measurements (Table. 1) suggest that such a transition from a diatom-dominated to a coccolithophore-dominated assemblage 

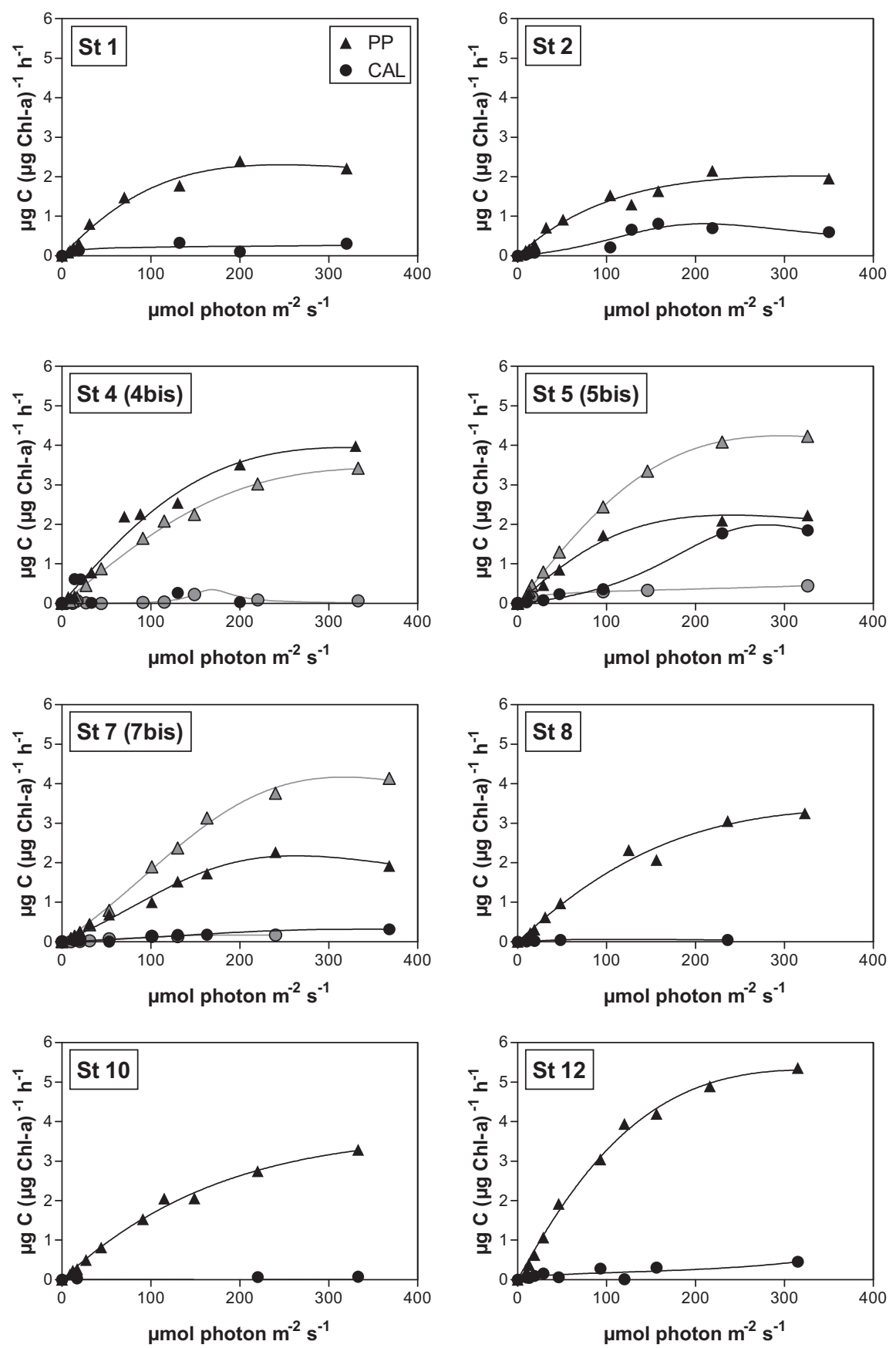

Fig. 10. Specific PP (filled triangles) and CAL (filled circles) rates as a function of irradiance (PAR) and their fit following the model of Eilers and Peeters (1988) in the northern Bay of Biscay (June 2004). The grey symbols and curves correspond to the re-visited stations 4 bis, 5 bis and 7 bis.

was probably occurring during the cruise. The rates of integrated $\mathrm{PP}$ were low within and outside the HR patch $\left(<700 \mathrm{mg} \mathrm{C} \mathrm{m}^{-2} \mathrm{~d}^{-1}\right)$, and were globally lower than the rates of $1030-1310 \mathrm{mg} \mathrm{C} \mathrm{m}^{-2} \mathrm{~d}^{-1}$ reported in early phases of coccolithophore blooms (Table 2), for example in the North Sea (Marañón and González, 1997). Nevertheless, our PP values agreed with those reported in a well developed coccolithophore bloom off the Shetland Islands (512$627 \mathrm{mg} \mathrm{C} \mathrm{m}^{-2} \mathrm{~d}^{-1}$; van der Wal et al., 1995) or in an early bloom off Iceland (510-620 $\mathrm{mg} \mathrm{C} \mathrm{m}^{-2} \mathrm{~d}^{-1}$; Rees et al., 2002). The PP values obtained during our cruise are nevertheless consistent with those reported by Joint et al. (2001) in the area at the continental slope at the same period of the year, and distinctly lower than PP values in the same area reported by these authors in April and
May ( $\sim 1000 \mathrm{mg} \mathrm{C} \mathrm{m}^{-2} \mathrm{~d}^{-1}$ ). The highest integrated CAL value of $141 \mathrm{mg} \mathrm{C} \mathrm{m}^{-2} \mathrm{~d}^{-1}$ determined over the continental slope during the present study corresponded to the CAL values of early bloom phases (e. g. Head et al., 1998). In contrast, the CAL:PP ratios reported inside the HR patch $(>0.16$ over the shelf) were similar to those found in late phases of blooms (Marañón and González, 1997). This spatial heterogeneity of PP, CAL and CAL:PP ratios in the study zone probably resulted from highly contrasted physical settings between stations with strong vertical mixing at the continental slope and more stratified conditions on the continental shelf.

The comparison of the satellite reflectance image (essentially a snapshot) and the measured vertical profiles of PIC (obtained dur- 

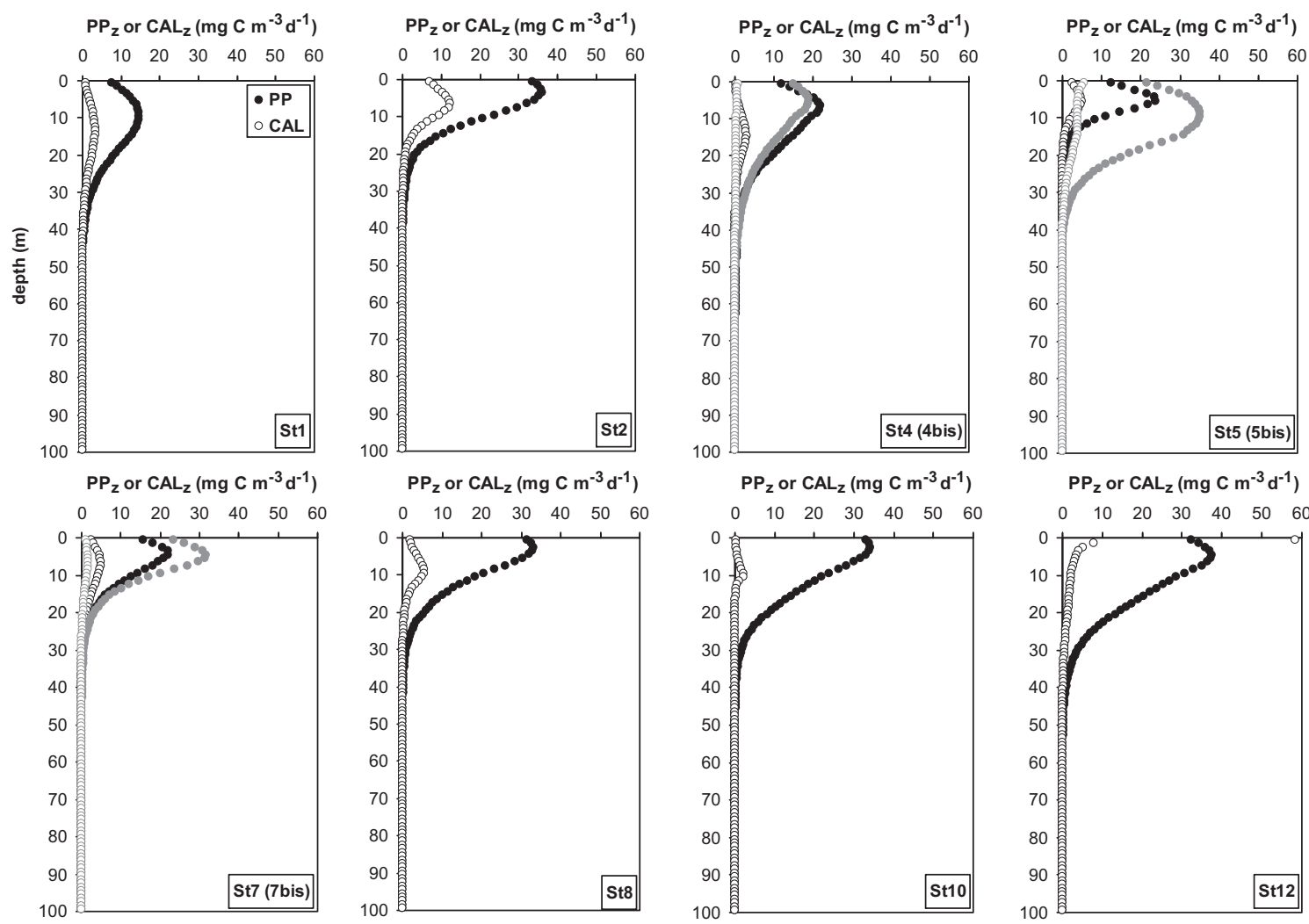

Fig. 11. Vertical profiles of daily $\mathrm{PP}_{z}$ (filled circles) and $\mathrm{CAL}_{z}$ (open circles) rates in the northern Bay of Biscay (June 2004). The grey symbols correspond to the vertical profiles at the re-visited stations (4bis, 5bis and 7bis). These parameters were not sampled at stations 3 and 6.

ing a $16 \mathrm{~d}$ cruise) could be misleading because of the temporal evolution of the bloom and advection of water masses. For example, station 1 was located outside the HR patch at the start of the cruise (3 June 2004) as testified by the low PIC concentrations
( $<24 \mu \mathrm{g} \mathrm{C} \mathrm{L}^{-1}$ ), which was not the case $10 \mathrm{~d}$ later when the remote sensed image was obtained (Fig. 1b). This also suggests that water mass motion and/or bloom development have spatial and time scales of $\sim 8 \mathrm{~d}$ and $\sim 70 \mathrm{~km}\left(\sim 0.1 \mathrm{~m} \mathrm{~s}^{-1}\right)$, in agreement with the

Table 2

Comparison of biogeochemical variables during coccolithophore blooms in the continental shelves and open waters of the North Atlantic compiled from literature and based on the present study in June 2004 in the northern Bay of Biscay.

\begin{tabular}{|c|c|c|c|c|c|c|c|c|}
\hline & $\begin{array}{l}\text { Northern } \\
\text { North Atlantic }\end{array}$ & $\begin{array}{l}\text { English } \\
\text { Channel }\end{array}$ & North Sea & Celtic Sea & North Sea & $\begin{array}{l}\text { Southern } \\
\text { Bay of } \\
\text { Biscay }\end{array}$ & North Sea & $\begin{array}{l}\text { Northern } \\
\text { Bay of Biscay }\end{array}$ \\
\hline Date & June 1991 & June 1992 & June - July 1993 & April-May 1994 & June -July 1994 & April 1998 & June 1999 & early June 2004 \\
\hline References & $\begin{array}{l}\text { Fernández et al. } \\
\text { (1993) and } \\
\text { Holligan et al. } \\
(1993 a, b)\end{array}$ & $\begin{array}{l}\text { Garcia-Soto } \\
\text { et al. (1995) }\end{array}$ & $\begin{array}{l}\text { van der Wal } \\
\text { et al. (1995) }\end{array}$ & Rees et al. (1999) & $\begin{array}{l}\text { Head et al. (1998), } \\
\text { Marañón and } \\
\text { González (1997) }\end{array}$ & $\begin{array}{l}\text { Lampert } \\
\text { et al. (2002) }\end{array}$ & $\begin{array}{l}\text { Rees } \\
\text { et al. (2002) }\end{array}$ & this study \\
\hline State of development & Late bloom & Dissipative & End bloom & $\begin{array}{l}\text { Diatom bloom } \\
\text { (Goban Spur) }\end{array}$ & Early bloom & & Early Bloom & Intermediate \\
\hline SST $\left[{ }^{\circ} \mathrm{C}\right]$ & 15.0 & $15.4-17.2$ & $7.6-13.0$ & 11.0 & $9.5-11.0$ & & 11.0 & $14.0-17.0$ \\
\hline $\mathrm{PO}_{4}\left[\mu \mathrm{mol} \mathrm{L}^{-1}\right]$ & & $<0.04$ & 0.1 & $0.25-0.55$ & $0.3-0.5$ & & $<0.06$ & $<0.1$ \\
\hline Chl-a $\left[\mu \mathrm{g} \mathrm{L}^{-1}\right]$ & $<1.0$ & $<0.5$ & $0.9-1.2$ & $0.5-5.3$ & $\sim 1.0$ & $0.8-1.1$ & $0.4-1.37$ & $0.75-1.5$ \\
\hline $\mathrm{POC}\left[\mu \mathrm{g} \mathrm{L}^{-1}\right]$ & $<204$ & $<48$ & $228-336$ & & $200-230$ & & & $120-192$ \\
\hline $\mathrm{PIC}\left[\mu \mathrm{g} \mathrm{L}^{-1}\right]$ & $>300$ & 300 & & & $27-50$ & & & $<96$ \\
\hline PIC:POC ratio & & & $\sim 0.4$ & & $<0.25$ & & & 0.20 to 0.89 \\
\hline $\begin{array}{l}\text { Coccolithophores } \\
\text { density }\left[10^{6} \text { cells } \mathrm{L}^{-1}\right]\end{array}$ & $1-5$ & $>2$ & 3 & & $2.24(\max 4.5)$ & $0.5-3.2$ & $0.76-2.3$ & $2.0-8.0$ \\
\hline $\begin{array}{l}\text { Cocoliths density } \\
{\left[10^{6} \text { liths } \mathrm{L}^{-1}\right]}\end{array}$ & $<350$ & $>350$ & $281-350$ & & $24-30$ & $<86$ & $281-350$ & $1-53$ \\
\hline suspended cocoliths: Cell & $20-40$ & $>175$ & $<200$ & & $7-34$ & & $<200$ & $3-10$ \\
\hline $\mathrm{PP}_{\mathrm{z}}\left[\mu \mathrm{g} \mathrm{POC} \mathrm{L}^{-1} \mathrm{~h}^{-1}\right]$ & $4.0-6.0$ & & & & $2.2-5.0$ & & 1.2 & $0.8-1.6$ \\
\hline $\mathrm{CAL}_{\mathrm{z}}\left[\mu \mathrm{g}\right.$ PIC $\left.\mathrm{L}^{-1} \mathrm{~h}^{-1}\right]$ & $0.6-1.5$ & & & & $0.7-1.1$ & & $<0.7$ & $<0.5$ \\
\hline $\mathrm{CAL}_{\mathrm{z}}: \mathrm{PP}_{\mathrm{z}}$ ratio & & & & & $0.25-0.43$ & & & $0.10-0.44$ \\
\hline $\mathrm{PP}\left[\mathrm{mg} \mathrm{C} \mathrm{m}{ }^{-2} \mathrm{~d}^{-1}\right]$ & $<1000$ & & $512-627$ & $500-1100$ & $1030-1310$ & & $510-620(<1090)$ & $210-680$ \\
\hline $\mathrm{CAL}\left[\mathrm{mg} \mathrm{C} \mathrm{m}^{-2} \mathrm{~d}^{-1}\right]$ & $151-196$ & & $21-94$ & & 135 & & $18-21(<138)$ & $14-140$ \\
\hline CAL:PP ratio & $0.14-0.19$ & & $0.03-0.18$ & & $0.14-0.16$ & & $0.03-0.18$ & $<0.31$ \\
\hline$\Delta \mathrm{TA}\left[\mu \mathrm{mol} \mathrm{kg}^{-1}\right]$ & $<40$ & & & & $10-20$ & & & $<40$ \\
\hline $\mathrm{pCO}_{2}[\mu \mathrm{atm}]$ & $310-340$ & & & & $>375$ & & & $260-350$ \\
\hline
\end{tabular}


average surface residual current speeds and direction in this area and during this period of the year (Huthnance et al., 2001), and typical time scales of coccolithophore bloom development (e.g. Delille et al., 2005).

\subsection{Times series of Chl-a and reflectance seasonal characterization of bloom status}

The analysis of the time series of remotely sensed surface parameters during spring and summer 2004 shows the onset of the spring phytoplankton bloom (i.e. Chl-a) in April 2004 at the La Chapelle Bank area (corresponding to station 2) (Fig. 12). The gradual increase of SST by c.a. $8^{\circ} \mathrm{C}$ from April to July 2004 was accompanied by a shoaling of the MLD from $145 \mathrm{~m}$ to $20 \mathrm{~m}$. Storm events increased MLD down to $100 \mathrm{~m}$ depth at several occasions during spring and summer and in particular in early May, prior to the cruise. A second peak of Chl-a of larger amplitude occurred in mid-May as the MLD shoaled to $40 \mathrm{~m}$, and was accompanied by a strong increase in the normalized water-leaving radiance at $555 \mathrm{~nm} L_{\mathrm{wn}}(555)$, indicative of the presence of coccolithophores in surface waters (GREPMA, 1988; Holligan et al., 1993a; Ackleson et al., 1994; Garcia-Soto et al., 1995; Gordon and Du, 2001; Gondwe et al., 2001; Lampert et al., 2002). The optical signature of the coccolithophore bloom $L_{\mathrm{wn}}(555)$ persisted in surface waters from May until July 2004 , as SST increased to $\sim 19{ }^{\circ} \mathrm{C}$ leading to an increased thermal stratification of the upper water column with a MLD of $20 \mathrm{~m}$. Strong stratification conditions favour the development of coccolithophore blooms when incoming irradiance is high (Nanninga and Tyrrell, 1996; Tyrrell and Merico, 2004). The $L_{\mathrm{wn}}(555)$ signal was observed from early June to mid-July as Chla declined, and values for both quantities in August were close to winter-time background values. Similar observations were made by Lampert et al. (2002) over the continental Armorican shelf in spring 1998, where spectral signature of coccolithophores was also observed from May to mid-July. The cruise was carried out during conditions of increasing stratification, decreasing surface Chl-a concentration and stable HR. The time elapsed between the appearance of the optical signature of the coccolithophore bloom $L_{\mathrm{wn}}(555)$ and start of the cruise was approximately $15 \mathrm{~d}$.

It may be considered as a common pattern that coccolithophore blooms follow the decline of the spring diatom bloom (Garcia-Soto et al., 1995; Lampert et al., 2002). It was proposed by Merico et al. (2006) that bloom-forming opportunistic species of coccolithophores such as E. huxleyi benefit, at temperate latitudes, from the low $\mathrm{pCO}_{2}$ conditions after intensive diatom production, which increases the $\Omega_{\text {cal }}$. These conditions, in conjunction with low grazing pressure on small phytoplankton, low inorganic nutrients, a strong affinity for organic nutrients (Paasche, 2002) and for high irradiance conditions (i.e. stratified waters) probably favour the development of coccolithophores.

The accumulation time of calcite in the water column was estimated by the ratio of PIC standing stock to CAL (Table 1), and compared to the time elapsed since the onset of calcite accumulation (i.e. $\sim 30 \mathrm{~d}$ from mid-May to mid-June, Fig. 12). Outside the HR patch, the computed accumulation time of calcite was generally lower than or close to $30 \mathrm{~d}$, suggesting that the CAL rates determined were too high compared to the PIC standing stock. On the contrary, at stations where HR was observed, the accumulation time largely exceeded $30 \mathrm{~d}(88 \mathrm{~d}$ and $117 \mathrm{~d}$ at stations 5 and 10 , respectively), suggesting that CAL values were not sufficient to account for the PIC standing stock. These discrepancies suggest that the pelagic community was not in equilibrium with respect to $\mathrm{CaCO}_{3}$ production and loss. This is further confirmed by the lack of agreement between CAL, PIC and E. huxleyi cell densities and $\triangle \mathrm{TA}$ (as discussed hereafter). Given the patchiness of phytoplankton biomass and composition, it is not surprising that discrepan-

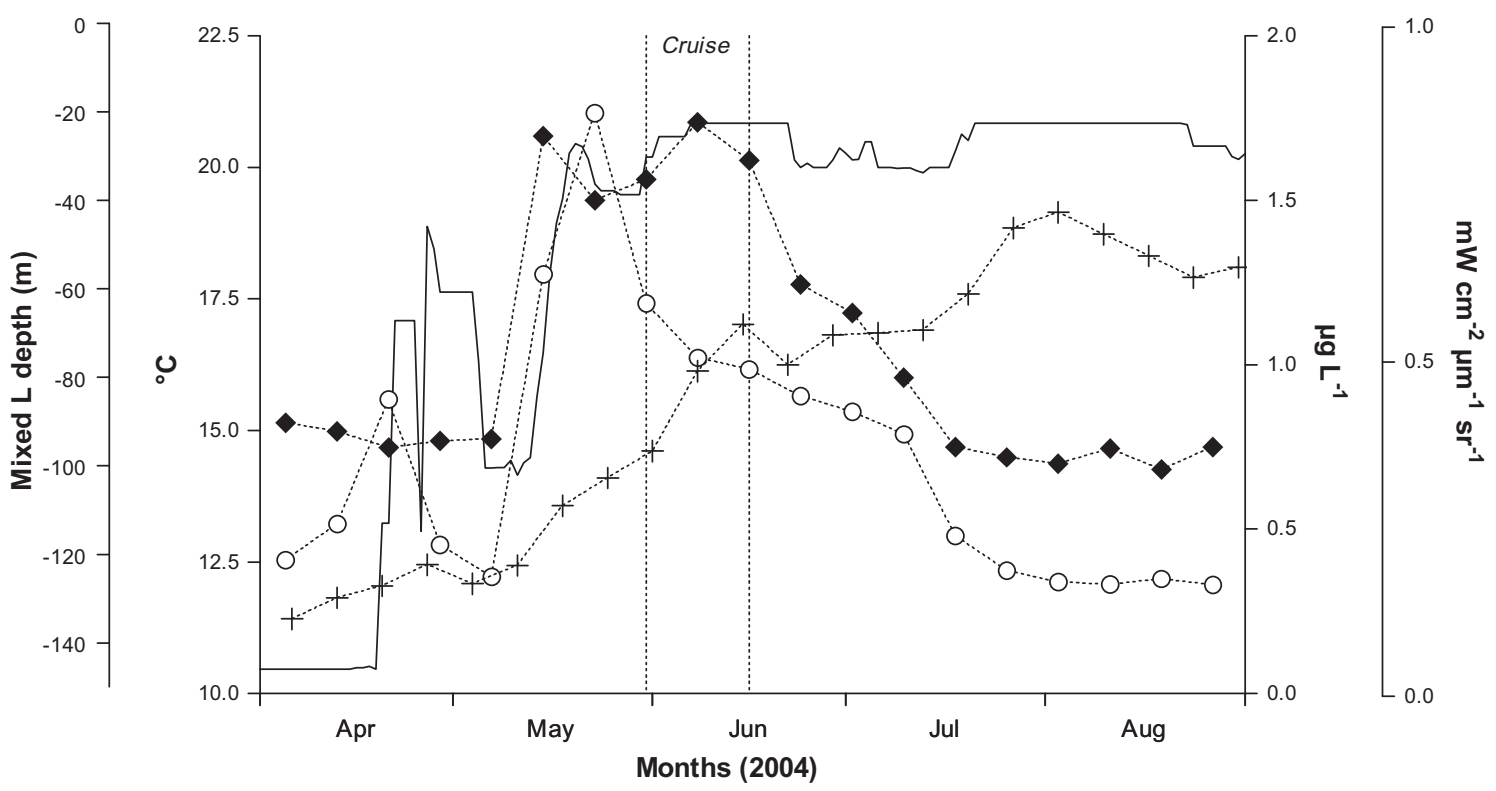

$$
\begin{aligned}
& \cdots \mathrm{L}_{\mathrm{wn}}(555)\left(\mathrm{mW} \mathrm{cm} \mathrm{cm}^{-2} \mathrm{sr}^{-1}\right) \\
& \text { …… Chl-a }\left(\mu \mathrm{g} \mathrm{L}^{-1}\right) \\
& \cdots+\cdots \operatorname{SST}\left({ }^{\circ} \mathrm{C}\right) \\
& \text { - MLD (m) }
\end{aligned}
$$

Fig. 12. Time series (in months from April to August) of weekly averaged Chl-a (Ocean Color Time-Series Online Visualization and Analysis web site, Level-3 Sea-viewing Wide Field-of-view Sensor (SeaWiFS), http://reason.gsfc.nasa.gov/Giovanni/) and normalized water-leaving radiance at $555 \mathrm{~nm}$ at the La Chapelle Bank (lat [47.5 ${ }^{\circ} \mathrm{N}, 48.0^{\circ} \mathrm{N}$ ]; long $\left[7.0^{\circ} \mathrm{W}, 6.0^{\circ} \mathrm{W}\right]$ ), mixed layer depth (Met Office National Centre for Ocean Forecasting for the North-East Atlantic (1/8 $\left.{ }^{\circ}\right)$ extracted from http://www.nerc-essc.ac.uk/ godiva/) and weekly averaged sea surface temperatures (Reynolds et al. (2002) weekly SST climatology (http://iridl.ldeo.columbia.edu/)) at [48 ${ }^{\circ} \mathrm{N}$; $6.5^{\circ} \mathrm{W}$ ] during the 2004 spring bloom. The vertical dashed lines correspond to the period of the cruise (1 June to 17 June 2004 ). 
cies are observed between production rates and standing stocks at different locations, since standing stocks are the result of various sources and sinks. The radio-tracer measurements, on the other hand, are instantaneous estimates of the rate of carbon fixation in a discrete sample over a specific incubation period. As a consequence, such differences may be due to different stages of bloom development: early stages (e.g. stations 7, 4, 12 and 2) were characterized by high CAL values associated with moderate to low PIC concentrations, and later stages (e.g. stations 10,8 and 5) were characterized by the accumulation of PIC in the water column due to high calcite production rates prior to the cruise, which were considerably reduced at the time of the cruise $\left(14 \mathrm{mg} \mathrm{C} \mathrm{m}^{-2} \mathrm{~d}^{-1}\right.$ at station 10 compared to $141 \mathrm{mg} \mathrm{C} \mathrm{m}^{-2} \mathrm{~d}^{-1}$ at station 5).

\subsection{Stoichiometry of calcite production}

For each mole of $\mathrm{CaCO}_{3}$ produced, TA decreases by $2 \mathrm{~mol}$ and $1 \mathrm{~mol}$ of $\mathrm{CO}_{2}$ is released to seawater from the bicarbonate pool, according to the stoichiometry of calcification (Eq. (1)). Deviation of TA with respect to conservative mixing was observed in the top $40 \mathrm{~m}$ (Fig 6b), which highlights the impact of coccolithophore calcification on seawater carbonate chemistry. The largest $\Delta T A$ value was observed at station $5\left(-49 \mu \mathrm{mol} \mathrm{kg}{ }^{-1}\right)$, where the most intense reflectance was also observed (Fig. 1c). At this station, PIC standing stocks (Fig. 8, Table 1), abundances of coccoliths and coccolithophores were also high (Fig. 9). However, no general pattern between $\triangle \mathrm{TA}$ and E. huxleyi cell density (nor PIC concentration) could be found for the whole data-set, as also reported in the North Sea by Head et al. (1998). The drawdown of TA is the signature of the biogeochemical history of the water mass, related to recent calcification events in the water mass, while E. huxleyi cell abundances (or PIC concentration) reflect the biomass of calcifiers at the time of sampling. The $\Delta \mathrm{TA}$ values we report are comparable to values of -25 to $-30 \mu \mathrm{mol} \mathrm{kg}{ }^{-1}$ reported in the Sargasso Sea by Bates et al. (1996) and in the North-eastern Atlantic Ocean by Holligan et al. (1993a), but lower than the values down to
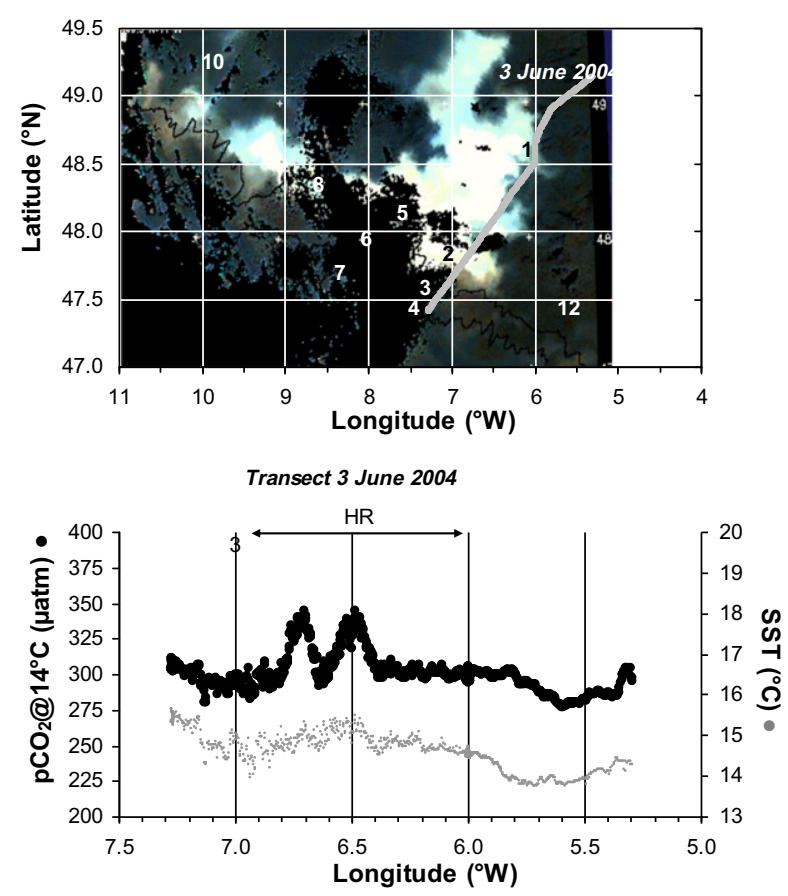

$-82 \mu \mathrm{mol} \mathrm{kg}{ }^{-1}$ reported in the Bering Sea by Murata and Takizawa (2002).

\subsection{Spatial variability of $\mathrm{pCO}_{2}$}

Pelagic biogenic calcification has been shown by Purdie and Finch (1994) and Crawford and Purdie (1997) to represent a source of $\mathrm{CO}_{2}$ to the water mass and a potential source of $\mathrm{CO}_{2}$ to the atmosphere, when the release to the water column of $\mathrm{CO}_{2}$ exceeds its consumption by net organic carbon formation (e.g. Head et al., 1998). The effect of calcification on surface seawater carbonate chemistry increased $\mathrm{pCO}_{2}$ values by $\sim 15 \mu \mathrm{atm}$ in a huge coccolithophore bloom in the North Atlantic (Robertson et al., 1994), and by $\sim 25 \mu$ atm in the northern North Sea (Buitenhuis et al. 1996, 2001). Bates et al. (1996) reported TA depletion in the upper water column of the Sargasso Sea associated with higher $\mathrm{pCO}_{2}$ values, as the probable biogeochemical signature of calcification. During the first leg of the cruise, $\Delta \mathrm{TA}$ and $\mathrm{pCO}_{2} @ 14{ }^{\circ} \mathrm{C}$ in surface waters were negatively correlated. The observed increase of $\mathrm{pCO}_{2} @ 14{ }^{\circ} \mathrm{C}$ from the $\Delta \mathrm{TA}$ values close to 0 to the most negative $\Delta \mathrm{TA}$ value of $-49 \mu \mathrm{mol} \mathrm{kg}^{-1}$ is about $80 \mu \mathrm{atm}$, based on the data from the first leg of the cruise (Fig. 6b). However, the theoretical computation of the change of seawater carbonate chemistry speciation related to a TA drawdown of $-49 \mu \mathrm{mol} \mathrm{kg}^{-1}$ due to calcification yields a lower increase of $\mathrm{pCO}_{2} @ 14{ }^{\circ} \mathrm{C}$ of about $22 \mu \mathrm{atm}$. Hence, other processes in addition to calcification contributed to negative relationship between $\triangle \mathrm{TA}$ and $\mathrm{pCO}_{2} @ 14^{\circ} \mathrm{C}$. As the TA signal is a cumulative signal of calcification during the whole history of the water mass, the most negative $\Delta \mathrm{TA}$ values may be where the surface community has developed towards a less autotrophic state or even a net heterotrophic state leading to an increase of $\mathrm{pCO}_{2} @ 14^{\circ} \mathrm{C}$ values in surface waters. The pattern between $\Delta \mathrm{TA}$ and $\mathrm{pCO}_{2} @ 14{ }^{\circ} \mathrm{C}$ is consistent with the analysis of the changes of underway $\mathrm{pCO}_{2} @ 14{ }^{\circ} \mathrm{C}$ along transects across the continental shelf, indicating an increase of $\mathrm{pCO}_{2} @ 14{ }^{\circ} \mathrm{C}$ in the $\mathrm{HR}$ areas (Fig. 13). Along the transect carried out on June 3, pCO $\mathrm{g}_{2} 14{ }^{\circ} \mathrm{C}$
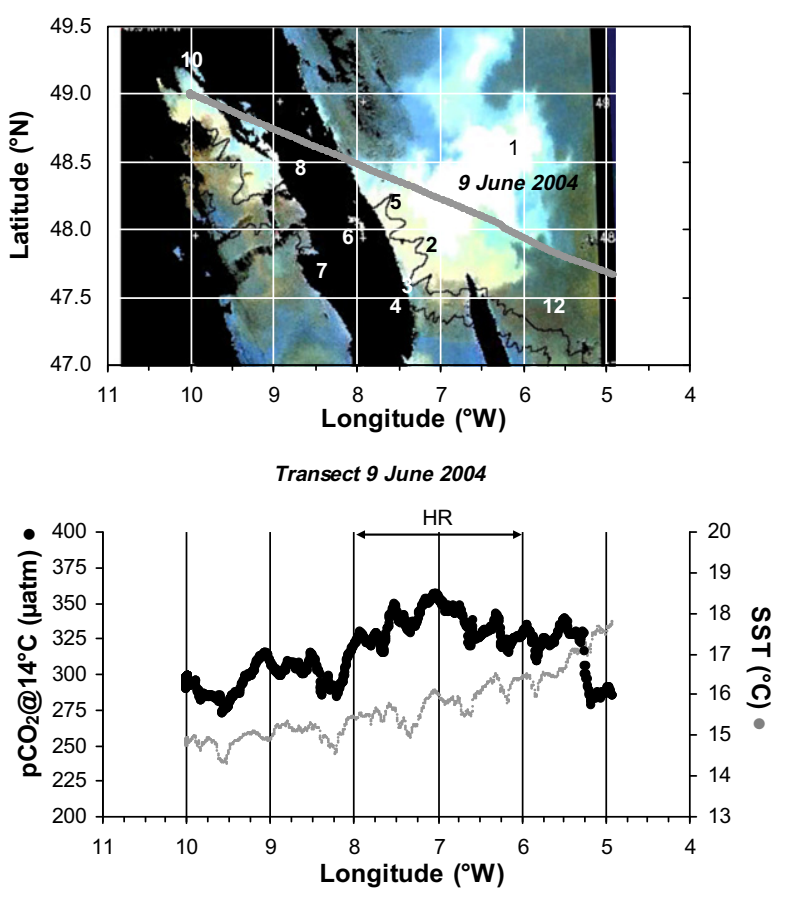

Fig. 13. Ship-track and stations superposed on the satellite reflectance images on 3 and 9 June 2004 (upper panel) and the distribution of pCO ${ }_{2} 14{ }^{\circ} \mathrm{C}(\mu$ atm, black symbols) and SST $\left({ }^{\circ} \mathrm{C}\right.$, grey symbols) as a function of longitude along two transects across HR patches in the northern Bay of Biscay. 
values were as high as $345 \mu \mathrm{atm}$ in the HR patch, higher than $\mathrm{pCO}_{2} @ 14{ }^{\circ} \mathrm{C}$ values outside the HR patch (both north and south) ranging between 280 and $305 \mu \mathrm{atm}$. Similarly, along the transect carried out on June $9, \mathrm{pCO}_{2} @ 14{ }^{\circ} \mathrm{C}$ values within the $\mathrm{HR}$ patch were as high as $355 \mu \mathrm{atm}$, higher than $\mathrm{pCO}_{2} @ 14{ }^{\circ} \mathrm{C}$ values outside the HR patch (both east and west) ranging between 280 and $340 \mu \mathrm{atm}$. While some of small scale horizontal variability of $\mathrm{pCO}_{2} @ 14{ }^{\circ} \mathrm{C}$ seemed to be related to changes in SST (with relatively colder waters associated to lower $\mathrm{pCO}_{2} @ 14{ }^{\circ} \mathrm{C}$ ), this does not explain the differences between $\mathrm{pCO}_{2} @ 14{ }^{\circ} \mathrm{C}$ values within and outside the HR patches. Such patterns of $\mathrm{pCO}_{2}$ in surface waters within and outside HR patches are in agreement with the observations of Holligan et al. (1993a) during a coccolithophore bloom off Iceland. The coccolithophore bloom investigated herein did not induce over-saturation of $\mathrm{CO}_{2}$ with respect to atmospheric equilibrium, but CAL contributed locally to an increase of the sea surface $\mathrm{pCO}_{2}$ up to $45 \mu \mathrm{atm}$. This increase of $\mathrm{pCO}_{2}$ was insufficient to overcome the background under-saturation of $\mathrm{CO}_{2}$ related to the biogeochemical history of the water masses due to net organic carbon fixation during the successive phytoplankton blooms in the area prior to the cruise (e.g. Frankignoulle and Borges, 2001; Wollast and Chou 2001b; Borges et al., 2006). This was also observed during E. huxleyi blooms in mesocoms, where a systematic decrease of $\mathrm{pCO}_{2}$ was observed during the exponential growth phase, and the increase of $\mathrm{pCO}_{2}$ during the decaying phase did not re-establish the initial $\mathrm{pCO}_{2}$ values (Delille et al., 2005; Riebesell et al., 2007).

\subsection{Organic and inorganic C cell-quotas}

The comparison of biogeochemical data related to coccolithophores obtained in controlled experiments and in the field is difficult because of the variability of natural phytoplankton assemblages compared to monospecific strains used in laboratory experiments or induced dominance at community level in mesocosm experiments, where the biomass of E. huxleyi may account for up to $70 \%$ of the total biomass (van der Wal et al., 1994; Engel et al., 2005). Assuming an organic carbon cell quota of $13 \mathrm{pg}$ C [ 1 picogram $=10^{-12} \mathrm{~g}$ ] (Holligan et al., 1983) and in situ cell abundances, the contribution of coccolithophore organic carbon biomass represented a maximum of $25 \%$ of the POC at stations 2,4 and 7 but their contribution increased to 33\% (station 8) and up to $75 \%$ at station 5 , where the HR patch was observed (Fig. 14). A similar range of values was also reported during an early bloom off the Shetland Islands in 1994, where the coccolithophore contribution to POC never exceeded 30\% (Marañón and González, 1997; $6.4-19.7 \%$ in Head et al., 1998) or ranged between 40 and $90 \%$ along a transect across a coccolithophore bloom off Iceland (Fernández et al., 1993).

The coccolith equivalent concentrations were calculated down to $150 \mathrm{~m}$ depth as the concentration of free plus attached coccoliths, considering a coverage of 20 liths cell $^{-1}$ (Fernández et al., 1993) and plotted against PIC concentrations (not shown). A calcite-C content of $0.39 \quad( \pm 0.07) 10^{-12} \mathrm{~g} \mathrm{C}$ lith $^{-1} \quad\left(r^{2}=0.50\right.$, $p<0.0001, n=32$ ) was obtained, which is consistent with the values of $0.28 \times 10^{-12} \mathrm{~g} \mathrm{Clith}^{-1}$ in a Norwegian Fjord (Fagerbakke et al., 1994), $0.26 \times 10^{-12} \mathrm{~g} \mathrm{Clith}^{-1}$ in the Gulf of Maine (Balch et al., 1991), $0.47( \pm 0.17) 10^{-12} \mathrm{~g} \mathrm{C}$ lith $^{-1}$ in the NE Atlantic (Fernández et al., 1993), $0.50-0.60 \times 10^{-12} \mathrm{~g} \mathrm{C}$ lith $^{-1}$ in the central North Atlantic (Holligan et al., 1983), and $0.28 \times 10^{-12} \mathrm{~g} \mathrm{Clith}^{-1}$ in sediment trap samples in the North Atlantic (Young and Ziveri, 2000), but lower than the value of $0.87 \times 10^{-12} \mathrm{~g} \mathrm{C}$ lith $^{-1}$ in the English Channel (Garcia-Soto et al., 1995). Only half of the variance of the distribution of the coccolith equivalent concentration is explained by the calculated calcite- $C$ content regression fit. This differs from the measurements by Fernández et al. (1993; $r^{2}=0.92$, $n=67$ ) that were obtained during early stages of the coccolithophore bloom. One possible explanation of the lower determination coefficient of the fit from our data could be attributed to heterogeneity in the relative abundance of $E$. huxleyi and other coccolithophore species, or supra-lysoclinal dissolution of $\mathrm{CaCO}_{3}$ (Wollast and Chou, 1998; Milliman et al., 1999; Lampert et al., 2002;
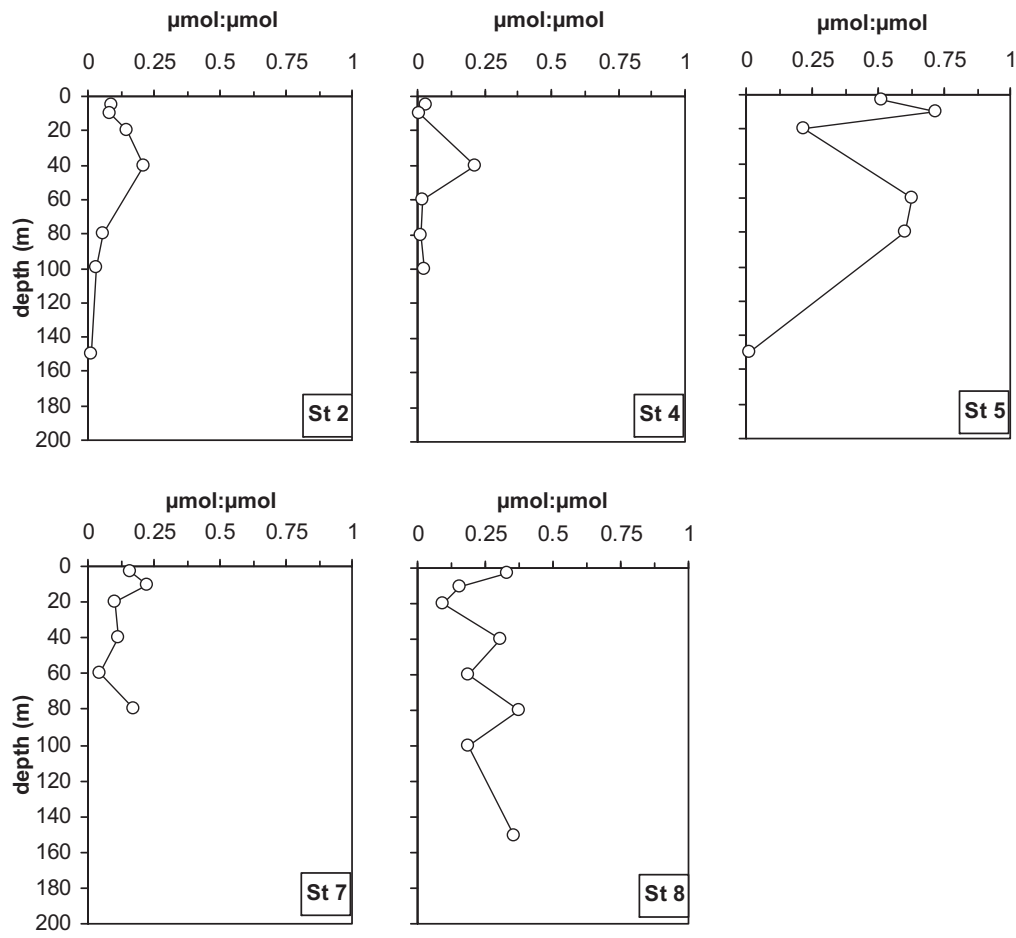

Fig. 14. Relative molar contribution of coccolithophore POC to the bulk POC, based on a cellular C-quota of 13 pg C and cell abundance in the northern Bay of Biscay (June 2004). 
Beaufort et al., 2007). Other explanations could be: the presence of less heavily calcified morphotypes of E. huxleyi (Beaufort and Heussner, 2001), the presence of malformed coccoliths with under-calcified liths (Riebesell et al., 2000), or the variation of the lith:coccosphere ratio (Balch et al., 1996) during the development of individuals, as observed in cultures (Beaufort et al., 2007) and in mesocosms (Engel et al., 2005). For these reasons, the direct transposition of such a relationship to estimates of $\mathrm{CaCO}_{3}$ dissolution rates in the field was not possible from our data-set.

\subsection{TEP concentration and potential for $C$ export}

TEP-C estimates in the top $40 \mathrm{~m}$ averaged $29.0 \pm 4.2 \mu \mathrm{g} \mathrm{C} \mathrm{L}^{-1}$ ( $n=54$ ), ranging from $8.5 \mu \mathrm{g} \mathrm{C} \mathrm{L}^{-1}$ (stations $5,30 \mathrm{~m}$ ) to $75.3 \mu \mathrm{g} \mathrm{C} \mathrm{L}^{-1}$ (station 7bis, $10 \mathrm{~m}$ ). The contribution of TEP-C to the POC in the top $40 \mathrm{~m}$ averaged $26 \pm 4 \%(n=31)$, which is higher than previous estimates in the same area (12\%; Harlay et al., 2009), along a transect in the northeast North Atlantic (17 $\pm 7 \%$; Engel, 2004), and in the Bay of Bengal (7\%; Bhaskar and Bhosle, 2006).

The physiological processes underlying polysaccharide exudation and TEP production are not well understood in coccolithophores, but TEP production by coccolithophores has been observed in batch cultures (Passow and Alldredge, 1995a) and mesocosm blooms (Engel et al., 2004). The release of polysaccharides by coccolithophores during calcification is linked to the internal mechanism of calcification (Marsh, 2003). The coccolith vesicle in which the coccolith grows is oversaturated with respect to calcite because polysaccharides have a strong affinity for $\mathrm{Ca}^{2+}$ and calcification probably plays the role of a "trash-can" to regulate the $\mathrm{Ca}^{2+}$ concentration in the cytosol (Kaźmierczak et al., 1985). Under nutrient-depleted conditions, the $C$ fixed by photosynthesis by diatoms in excess to $\mathrm{N}$ and $\mathrm{P}$ (deviating from the Redfield $\mathrm{C}: \mathrm{N}: \mathrm{P}$ stoichiometry) leads to the formation and exudation of dissolved organic carbon-rich compounds, such as polysaccharides, that act as precursors to the formation of TEP (Engel et al., 2002; Schartau et al., 2007). If such a model of C-over-consumption also applies to coccolithophores for which calcification is linked to the production of polysaccharides, one can assume that this process is relevant in the coccolithophore $\mathrm{C}$ budgets and to date, probably, has been under-evaluated. In the absence of TEP, suspended coccoliths may remain several weeks in the water column before settling (Broerse et al., 2000b). The accumulation of TEP during coccolithophore blooms could result in the formation of aggregates leading to massive aggregation events that "wash" out surface waters of detritus and particles. The potential importance of TEP-C in POC standing stock and enhancement of $C$ export, hence, for the biological pump (Santschi et al., 2002; De La Rocha and Passow, 2007; Harlay et al., 2009), is strengthened during coccolithophore blooms because of the ballast effect of calcite in aggregates (Broerse et al., 2000a; Ziveri et al., 2000, 2007). Several studies by Cadée (1985), De Wilde et al. (1998), McCave et al. (2001) have reported the presence of gelatinous aggregates with embedded intact coccoliths or coccolithophore cells at the surface sediments during or after the spring bloom. If one links the bottom deposits to the production of TEP by phytoplankton, due to $C$ over-consumption, this mechanism would be relevant to better quantify the export of particulate matter (organic and inorganic) to depth during coccolithophore blooms and its possible modification (and related feed-back) in the context of climate change.

\subsection{Bacterial production and density}

Phytoplankton exudates and subsequent aggregation have a significant impact on bacterial physiology (Kepkay, 1994; Bhaskar et al., 2005; Azetsu-Scott and Passow, 2004). In a mesocosm study during which blooms of diatoms and of E. huxleyi occurred, the bacterial dynamics underwent changes during the course of the experiment, leading to bacterial production rates higher in the pool of attached bacteria than in the pool of free-living bacteria after the exponential phytoplankton growth phase (Grossart et al., 2006). During this cruise, the free-living and attached bacterial communities were not discriminated in measurements of abundance and production; however, epifluorescence microscopic observations suggested that, in surface samples, bacteria were often associated to organic substrates, probably of colloidal origin. BPP rates determined in the surface layer during the survey (ranging between 0.26 and $0.71 \mu \mathrm{g} \mathrm{C} \mathrm{L}^{-1} \mathrm{~h}^{-1}$ ) were similar to those determined by Grossart et al. (2006) in mesocosm experiments before the formation of aggregates. Average BPP rates were one order of magnitude higher than those reported during the early stage of development of an E. huxleyi bloom in the North Sea in June 1999 (0.05 \pm $0.01 \mu \mathrm{g} \mathrm{C} \mathrm{L}^{-1} \mathrm{~h}^{-1}$; Zubkov et al., 2002). No significant correlation was found between bacterial abundance and either TEP or Chl-a, although a correlation was found with POC concentration $\left(r^{2}=0.53, n=56\right)$. One reason may be that TEP, according to the definition by Passow and Alldredge (1995a), represent a fraction of the colloidal matrix in aggregates whose $C$ pool does not necessarily stain with Alcian blue (e.g. neutral polysaccharides, coomassie stained particles). Cell-specific BPP in surface waters ranged between 0.08 and $1.33 \mathrm{fg} \mathrm{C}$ cell $^{-1} \mathrm{~h}^{-1}$ [ 1 femtogram $=10^{-15} \mathrm{~g}$ ] in the HR patch (at stations 4 bis and 1, respectively) and did not exhibit major changes with time at re-visited stations 5bis and 7bis (Table 1). The apparent decrease of cell-specific BPP observed with time at station 4 (from $0.38 \mathrm{fg} \mathrm{C}$ cell $^{-1} \mathrm{~h}^{-1}$ to $0.08 \mathrm{fg} \mathrm{Cell}^{-1} \mathrm{~h}^{-1}$ ) was due the increase in $8 \mathrm{~d}$ of bacterial abundance by a factor 3 at this station.

\section{Conclusions}

The present study conducted at the continental margin of the northern Bay of Biscay is consistent with the general patterns observed during previous investigations of coccolithophore blooms (Balch et al., 1991; Fernández et al., 1993; van der Wal et al., 1994; Marañón and González, 1997, among others): the coccolithophore bloom was characterized by moderate Chl-a concentrations $\left(<1 \mu \mathrm{g} \mathrm{L}^{-1}\right)$ and high PIC concentrations $(\sim 8 \mu \mathrm{M})$ in the HR patch. Low $\mathrm{PO}_{4}$ and DSi concentrations, associated with low $\mathrm{pCO}_{2}$ and high $\Omega_{\text {cal }}$ probably favoured the coccolithophore bloom, as well as high irradiance and shallow water stratification (Tyrrell and Merico, 2004).

Different stages of the bloom were observed during the present study. Early stages of bloom development occurred over the continental slope (e.g. stations 4, 7), where low E. huxleyi cell densities and low coccolith:coccosphere ratios were observed. This contrasts with later stages of the bloom over the continental shelf, displaying higher CAL:PP ratios, HR and the highest E. huxleyi cell densities (e.g. station 2, 5). In this area, the onset of the bloom was probably triggered by the mixing at the shelf break and the bloom developed as the water-column stratified, as the water mass was advected over the continental shelf, following the general residual circulation in the area (Huthnance et al., 2001), resulted in massive HR patches spreading over the continental shelf. A similar hypothesis was proposed by Lampert et al. (2002) in the southern Bay of Biscay, with the difference that thermo-haline stratification occurred in areas influenced by riverine inputs while no halocline was observed in the area during the present study.

The behaviour of the different biogeochemical parameters is probably governed by the hydrodynamics in this region; in particular the inorganic carbon fraction of suspended material. Based on the sinking velocity of coccoliths and coccospheres, Holligan et al. (1993b) estimated that more than $200 \mathrm{~d}$ would be required for the 
coccolithophore optical signature to disappear from satellite images. However, several lines of evidence - among them the present study - suggest that the life-time of coccolithophore blooms does not exceed a period of $40 \mathrm{~d}$ which implies that physical mechanisms may be involved in the "washing" of suspended calcite out of surface waters. The particle aggregation enhanced by the presence of TEP and their sinking through the water column when ballasted with calcite is a likely process, together with grazing (Harris, 1994), that may act together for an efficient removal of calcite from surface waters.

During our study, high TEP concentrations were measured with a computed $\mathrm{C}$ content amounting to $26 \%$ of the POC. In parallel to the role of faecal pellets in calcite dissolution (Milliman et al., 1999), these aggregates may also constitute microenvironments hosting specific communities, from microbes to invertebrates, and could also play a role in the supra-lysoclinal dissolution of $\mathrm{CaCO}_{3}$. Beaufort et al. (2007) showed that calcite dissolution leads to the rapid disintegration, within a few hours, of the coccoliths into minute needles, due to the presence of weak parts in the solid structure of the liths (Young et al., 1999). If calcite dissolution occurs in the photic zone where the organic precursors for aggregates (TEP) are abundant, it is most probable that these minute calcite parts are more likely to be washed out and exported to depth during massive aggregation events.

Our understanding of the conditions leading to coccolithophore bloom development in the Bay of Biscay has increased but there is a lack of observations to describe the conditions for bloom termination and understand the associated mechanisms. Environmental pressures like viral lysis or zooplankton grazing have been shown to slow down cellular activity but have failed to explain the collapse of blooms over short periods of time (Delille et al., 2005). The study of processes like TEP production and events leading to massive aggregation and rapid export to depth remain to be described in order to better constrain the role of coccolithophores in the global $\mathrm{C}$ cycle.

\section{Acknowledgements}

We are grateful to the officers and crewmembers of the RV Belgica for their logistic support, Joan Backers, Jean-Pierre De Blauw and Gregory Deschepper of the Unit of the North Sea Mathematical Models for their support in data acquisition, J.-P. Vanderborght (ULB) for assistance and fruitful discussions during the writing of this manuscript, and 4 anonymous reviewers for constructive comments on a previous version of the manuscript. This work received financial support from the Belgian Federal Science Policy Office (Contracts No. EV/11/5A, EV/03/5B, EV/06/5C, SD/CS/03) and contributes to EU IP CARBOOCEAN (Contract No. 511176). S.G. acknowledges support from the Natural Environment Research Council (NERC) through Oceans 2025 theme 2 and the NERC Earth Observation Data Acquisition and Analysis Service. A.V.B. and B.D. are research associates at the FRS-FNRS.

\section{References}

Ackleson, S.G., Balch, W.M., Holligan, P., 1994. Response of water-leaving radiance to particulate calcite and chlorophyll a concentrations: a model for Gulf of Maine coccolithophore blooms. Journal of Geophysical Research 99,7483-7500.

Alldredge, A.L., Cole, J.J., Caron, D.A., 1986. Production of heterotrophic bacteria inhabiting macroscopic organic aggregates (marine snow) from surface waters. Limnology and Oceanography 31, 68-78.

Azetsu-Scott, K., Passow, U., 2004. Ascending marine particles: significance of transparent exopolymer particles (TEP) in the upper ocean. Limnology and Oceanography 49, 741-748.

Balch, W.M., Holligan, P., Ackleson, S.G., Voss, K.J., 1991. Biological and optica properties of mesoscale coccolithophore blooms in the Gulf of Maine. Limnology and Oceanography 36, 629-643.

Balch, W.M., Kilpatrick, K.A., Holligan, P., Harbour, D., Fernandez, E., 1996. The 1991 coccolithophore bloom in the central North Atlantic. 2. Relating optics to coccolith concentration. Limnology and Oceanography 41, 16841696.

Balch, W.M., Gordon, H.R., Bowler, B.C., Drapeau, D.T., Booth, E.S., 2005. Calcium carbonate measurements in the surface global ocean based on moderateresolution imaging spectroradiometer data. Journal of Geophysical Research 110, C07001. doi:10.1029/2004JC002560.

Balch, W.M. Drapeau, D. Bowler, B., Booth, E., 2007. Prediction of pelagic calcification rates using satellite measurements. Deep Sea Research Part II: Topical Studies in Oceanography 54, 478-495.

Bates, N.R., Michaels, A.F., Knap, A.H., 1996. Alkalinity changes in the Sargasso Sea: geochemical evidence of calcification? Marine Chemistry 51, 347-358.

Beaufort, L., Heussner, S., 2001. Seasonal dynamics of calcareous nannoplankton on a West European continental margin: the Bay of Biscay. Marine Micropaleontology 43, 27-55.

Beaufort, L., Probert, I., Buchet, N., 2007. Effects of acidification and primary production on coccolith weight: implications for carbonate transfer from the surface to the deep ocean. Geochemistry Geophysics Geosystems 8, 8011.

Benson, B.B., Krause, D., 1984. The concentration and isotopic fractionation of oxygen dissolved in freshwater and seawater in equilibrium with the atmosphere. Limnology Oceanography 29, 620-632.

Bhaskar, P.V., Bhosle, N.B., 2006. Dynamics of transparent exopolymeric particles (TEP) and particle-associated carbohydrates in the Dona Paula bay, west coast of India. Journal of Earth System Science 115, 403-413.

Bhaskar, P.V., Grossart, H.-P., Bhosle, N.B., Simon, M., 2005. Production of macroaggregates from dissolved exopolymeric substances (EPS) of bacterial and diatom origin. FEMS Microbiology Ecology 53, 255-264.

Bondarenko, I., Treiger, B., Van Grieken, R., Van Espen, P., 1996. IDAS: a Windows based software package for cluster analysis. Spectrochimica Acta Part B: Atomic Spectroscopy 51, 441-456.

Borges, A.V., Schiettecatte, L.-S., Abril, G., Delille, B., Gazeau, F. 2006. Carbon dioxide in European coastal waters. Estuarine, Coastal and Shelf Science 70 375-387.

Broerse, A.T.C., Ziveri, P., Honjo, S., 2000a. Coccolithophore $\left(-\mathrm{CaCO}_{3}\right)$ flux in the Sea of Okhotsk: seasonality, settling and alteration processes. Marine Micropaleontology 39, 179-200.

Broerse, A.T.C., Ziveri, P., Van Hinte, J.E., Honjo, S., 2000b. Coccolithophore export production, species composition, and coccolith-CaCO3 fluxes in the NE Atlantic $\left(34^{\circ} \mathrm{N} 21^{\circ} \mathrm{W}\right.$ and $\left.48^{\circ} \mathrm{N} 21^{\circ} \mathrm{W}\right)$. Deep Sea Research Part II: Topical Studies in Oceanography 47, 1877-1905.

Brown, C.W., Yoder, J.A., 1994. Coccolithophorid blooms in the global ocean. Journal of Geophysical Research 99, 7467-7482.

Buitenhuis, E., van Bleijswijk, J., Bakker, D., Veldhuis, M., 1996. Trends in inorganic and organic carbon in a bloom of Emiliania huxleyi in the North Sea. Marine Ecology Progress Series 143, 271-282.

Buitenhuis, E., van der Wal, P., de Baar, H., 2001. Blooms of Emiliania huxleyi are sinks of atmospheric carbon dioxide; a field and mesocosm study derived simulation. Global Biogeochemical Cycles 15, 577-588.

Cadée, G.C., 1985. Macroaggregates of Emiliana huxleyi in sediment traps. Marine Ecology Progress Series 24, 193-196.

Chin, W., Orellana, M.V., Verdugo, P., 1998. Spontaneous assembly of marine dissolved organic matter into polymer gels. Nature 391, 568-572.

Copin-Montégut, C., 1988. A new formula for the effect of temperature on the partial pressure of carbon dioxide in seawater. Marine Chemistry 25, 29-37.

Copin-Montégut, C., 1989. A new formula for the effect of temperature on the partial pressure of carbon dioxide in seawater, Corrigendum. Marine Chemistry 27, 143-144.

Crawford, D.W., Purdie, D.A., 1997. Increase of $\mathrm{pCO}_{2}$ during blooms of Emiliania huxleyi: theoretical considerations on the asymmetry between acquisition of $\mathrm{HCO}_{3}^{-}$and respiration of free $\mathrm{CO}_{2}$. Limnology and Oceanography 42 365-372.

De La Rocha, C.L., Passow, U., 2007. Factors influencing the sinking of POC and the efficiency of the biological carbon pump. Deep Sea Research Part II: Topical Studies in Oceanography 54, 639-658.

de Wilde, P.A.W.J., Duineveld, G.C.A., Berghuis, E.M., Lavaleye, M.S.S., Kok, A., 1998. Late-summer mass deposition of gelatinous phytodetritus along the slope of the N.W. European Continental Margin. Progress in Oceanography $42,165-187$

Delille, B., Harlay, J., Zondervan, I., Jacquet, S., Chou, L., Wollast, R., Bellerby, R.G.J., Frankignoulle, M., Borges, A.V., Riebesell, U., Gattuso, J.-P., 2005. Response of primary production and calcification to changes of $\mathrm{pCO}_{2}$ during experimental blooms of the coccolithophorid Emiliania huxleyi. Global Biogeochemical Cycles 19, GB2023.

Dickson, A.G., 1990. Thermodynamics of the dissociation of boric acid in synthetic seawater from 273.15 to 318.15 K. Deep Sea Research Part A. Oceanographic Research Papers 37, 755-766.

Dickson A.G., Sabine C.L., Christian J.R., 2007. Guide to Best Practices for Ocean $\mathrm{CO}_{2}$ Measurements. PICES Special Publication, vol. 191. North Pacific. IOCCP Report No. 8.

Egge, J.K., Aksnes, D.L., 1992. Silica as regulating nutrient in phytoplankton competition. Marine Ecology Progress Series 83, 281-289.

Eilers, P.H.C., Peeters, J.C.H., 1988. A model for the relationship between light intensity and the rate of photosynthesis in phytoplankton. Ecological Modeling $42,199-215$.

Engel, A., 2004. Distribution of transparent exopolymer particles (TEP) in the northeast Atlantic Ocean and their potential significance for aggregation processes. Deep Sea Research Part I: Oceanographic Research Papers 51, 83-92. 
Engel, A., Passow, U., 2001. Carbon and nitrogen content of transparent exopolymer particles (TEP) in relation to their Alcian Blue adsorption. Marine Ecology Progress Series 219, 1-10.

Engel, A., Schartau, M., 1999. Influence of transparent exopolymer particles (TEP) on sinking velocity of Nitzschia closterium aggregates. Marine Ecology Progress Series 182, 69-76.

Engel, A., Goldthwait, S., Passow, U., Alldredge, A.L., 2002. Temporal decoupling of carbon and nitrogen dynamics in a mesocosm diatom bloom. Limnology and Oceanography $47,753-761$

Engel, A., Delille, B., Jacquet, S., Riebesell, U., Rochelle-Newall, E., Terbruggen, A., Zondervan, I., 2004. Transparent exopolymer particles and dissolved organic carbon production by Emiliania huxleyi exposed to different $\mathrm{CO}_{2}$ concentrations: a mesocosm experiment. Aquatic Microbial Ecology 34, 93-104.

Engel, A., Zondervan, I., Aerts, K., Benthien, A., Chou, L., Delille, B., Gattuso, J.-P., Harlay, J., Heemann, C., Hoffmann, L., Jacquet, S., Nejstgaard, J., Pizay, M.-D., Rochelle-Newall, E., Schneider, U., Terbrueggen, A., Riebesell, U., 2005. Testing the direct effects of $\mathrm{CO}_{2}$ concentration on marine phytoplankton: a mesocosm experiment with the coccolithophorid Emiliania huxleyi. Limnology and Oceanography 50, 493-507.

Fagerbakke, K.M., Heldal, M., Norland, S., Heimdal, B.R., Båtvik, H., 1994. Chemical composition and size of coccoliths from enclosure experiments and a Norwegian fjord. Sarsia 79, 349-355.

Feely, R.A., Sabine, C.L., Lee, K., Millero, F.J., Lamb, M.F., Greeley, D., Bullister, J.L., Key, R.M., Peng, T.H., Kozyr, A., Ono, T., Wong, C.S., 2002. In situ calcium carbonate dissolution in the Pacific Ocean. Global Biogeochemical Cycles 16, 1144. doi:10.1029/2002 GB001866.

Fernández, E., Boyd, P.W., Holligan, P.M., Harbour, D.S., 1993. Production of organic and inorganic carbon within a large-scale coccolithophore bloom in the northeast Atlantic Ocean. Marine Ecology Progress Series 97, 271-285.

Frankignoulle, M., Borges, A.V., 2001. European continental shelf as a significant sink for atmospheric carbon dioxide. Global Biogeochemical Cycles 15, 569576.

Frankignoulle, M., Borges, A.V., Biondo, R., 2001. A new design of equilibrator to monitor carbon dioxide in highly dynamic and turbid environments. Water Research 35, 1344-1347.

Fritz, J.J., Balch, W.M., 1996. A light-limited continuous culture study of Emiliania huxleyi: a determination of coccolith detachment and its relevance to cell sinking. Journal of Experimental Marine Biology and Ecology 207, 127-147.

Garcia-Soto, C., Fernandez, E., Pingree, R.D., Harbour, D.S., 1995. Evolution and structure of a shelf coccolithophore bloom in the Western English Channel. Journal of Plankton Research 17, 2011-2036.

Godoi, R.H.M., Aerts, K., Harlay, J., Kaegi, R., Chul-Un, R., Chou, L., Van Grieken, R., 2009. Organic surface coating on coccolithophores - Emiliania huxleyi: its determination and implication in the marine carbon cycle. Microchemical Journal 91 (2), 266-271.

Gondwe, M., Klaasen, W., Gieskes, W., de Baar, H.J.W., 2001. The direct radiative impact of coccolithophore blooms on basin-scale climate. Geophysical Research Letters 28, 3911-3914.

Gordon, H.R., Du, T., 2001. Light scattering by nonspherical particles: application to coccoliths detached from Emiliania huxleyi. Limnology and Oceanography 46, 1438-1454.

Gran, G., 1952. Determination of the equivalence point in potentiometric titrations. Analyst (Part II) 661, 667

Grasshoff, K., Ehrhardt, M., Kremling, K., 1983. Methods of Seawater Analysis. Verlag Chemie, Weinheim.

GREPMA, 1988. Satellite (AVHRR:NOAA-9) and ship studies of a coccolithophorid bloom in the western English Channel (Viollier, M., Sournia, A., Birrien, M.-J., Chrétiennot-Dinet, P., Le Borgne, P., Le Corre, P., Morin, P., and Olry, J.P.). Marine Nature 1, 1-14

Grossart, H.-P., Allgaier, M., Passow, U., Riebesell, U., 2006. Testing the effect of $\mathrm{CO}_{2}$ concentration on the dynamics of marine heterotrophic bacterioplankton. Limnology and Oceanography 51, 1-11.

Harlay, J., De Bodt, C., Engel, A., Jansen, S., d'Hoop, Q., Piontek, J., Van Oostende, N., Groom, S., Sabbe, K., Chou, L., 2009. Abundance and size distribution of transparent exopolymer particles (TEP) in a coccolithophorid bloom in the northern Bay of Biscay. DSR Part I 56, 1251-1265.

Harris, R.P., 1994. Zooplankton grazing on the coccolithophore Emiliania huxleyi and its role in inorganic carbon flux. Marine Biology 119 (3), 431-439.

Head, R.N., Crawford, D.W., Egge, J.K., Harris, R.P., Kristiansen, S., Lesley, D.J., Marañon, E., Pond, D., Purdie, D.A., 1998. The hydrography and biology of a bloom of the coccolithophorid Emiliania huxleyi in the northern North Sea. Journal of Sea Research 39, 255-266.

Holligan, P.M., Viollier, M., Harbour, D.S., Camus, P., Champagne-Philippe, M., 1983. Satellite and ship studies of coccolithophore production along a continental shelf edge. Nature 304, 339-342.

Holligan, P.M., Fernández, E., Aiken, W., Balch, W.M., Boyd, P.W., Burkill, P.H., Finch, M., Groom, S.B., Malin, G., Muller, K., Purdie, D.A., Robinson, C., Trees, C.C., Turner, S.M., van der Wal, P., 1993a. A biogeochemical study of the coccolithophore, Emiliania huxleyi, in the North Atlantic. Global Biogeochemical Cycles 7, 879-900.

Holligan, P.M., Groom, S.B., Harbour, D.S., 1993b. What controls the distribution of the coccolithophore, Emiliania huxleyi, in the North Sea? Fisheries Oceanography $2,175-183$.

Honjo, S., Manganini, S.J., Krishfield, R.A., Francois, R., 2008. Particulate organic carbon fluxes to the ocean interior and factors controlling the biological pump: a synthesis of global sediment trap programs since 1983. Progress in Oceanography 76, 217-285.

Huthnance, J.M., Coelho, H., Griffiths, C.R., Knight, P.J., Rees, A.P., Sinha, B., Vangriesheim, A., White, M., Chatwin, P.G., 2001. Physical structures, advection and mixing in the region of Goban spur. Deep Sea Research Part II: Topical Studies in Oceanography 48, 2979-3021.

Joint, I, Wollast, R., Chou, L, Batten, S., Elskens, M., Edwards, E, Hirst, A, Burkill, P.H., Groom, S., Gibb, S., Miller, A., Hydes, D.J., Dehairs, F., Antia, A.N., Barlow, R., Rees, A., Pomroy, A., Brockmann, U., Cimmings, D., Lampitt, R., Loijens, M., Mantoura, F., Miller, P., Raabe, T., Alvarez-Salgado, X., Stelfox, C., Woolfenden, J., 2001. Pelagic production at the Celtic Sea shelf break. Deep Sea Research Part II: Topical Studies in Oceanography 48, 3049-3081.

Kaźmierczak, J., Ittekkot, V., Degens, E.T., 1985. Biocalcification through time: environmental challenge and cellular response. Paläontologische Zeitschrift 59 $(1-2), 15-33$

Kelly-Gerreyn, B.A., Hydes, D.J., Jegou, A.M., Lazure, P., Fernand, L.J., Puillat, I., Garcia-Soto, C., 2006. Low salinity intrusions in the western English Channel. Continental Shelf Research 26, 1241-1257.

Kepkay, P.E., 1994. Particle aggregation and the biological reactivity of colloids. Marine Ecology Progress Series 109, 293-304.

Kiorboe, T., 2000. Colonization of marine snow aggregates by invertebrate zooplankton: abundance, scaling, and possible role. Limnology and Oceanography $45,479-484$

Knap, A.H., Michaels, A.E., Close, A., Ducklow, H.W., Dickson, A.G., 1996. Protocols for the Joint Global Ocean Flux Study (JGOFS) core measurements. Bergen, Norway, UNESCO. JGOFS Report.

Lampert, L., Quéguiner, B., Labasque, T., Pichon, A., Lebreton, N., 2002. Spatial variability of phytoplankton composition and biomass on the eastern continental shelf of the Bay of Biscay (north-east Atlantic Ocean). Evidence for a bloom of Emiliania huxleyi (Prymnesiophyceae) in spring 1998. Continental Shelf Research 22, 1225-1247.

Lee, K.-S., 2001. Global net community production estimated from the annual cycle of surface water total dissolved inorganic carbon. Limnology and Oceanography $46,1287-1297$

Lewis, E., Wallace, D.W.R., 1998. Program Developed for $\mathrm{CO}_{2}$ System Calculations. ORNL/CDIAC. Carbon Dioxide Information Analysis Center, Oak Ridge National Laboratory. US Department of Energy, Oak Ridge, Tennessee.

Ling, S.C., Alldredge, A.L., 2003. Does the marine copepod Calanus pacificus consume transparent exopolymer particles (TEP)? Journal of Plankton Research 25, 507515

Linschooten, C., van Bleijswijk, J.D.L., Van Emburg, P.R., De Vrind, J.P.M., Kempers, E.S., Westbroek, P., De Vrind-De Jong, E.W., 1991. Role of light-dark cycle and medium composition on the production of coccoliths by Emiliania huxleyi (Haptophyceae). Journal of Phycology 27, 82-86.

Marañón, E., González, N., 1997. Primary production, calcification and macromolecular synthesis in a bloom of the coccolithophore Emiliania huxleyi in the North Sea. Marine Ecology Progress Series 157, 61-77.

Marañon, E., Fernandez, E., Harris, R.P., Harbour, D., 1996. Effects of the diatom - Emiliania huxleyi succession on photosynthesis, calcification and carbon metabolism by size-fractionated phytoplankton. Hydrobiologia 317, 189199.

Mari, X., Kiorboe, T., 1996. Abundance, size distribution and bacterial colonization of transparent exopolymeric particles (TEP) during spring in the Kattegat. Journal of Plankton Research 18, 969-986.

Mari, X., Rassoulzadegan, F., 2004. Role of TEP in the microbial food web structure. I. Grazing behavior of a bacterivorous pelagic ciliate. Marine Ecology Progress Series 279, 13-22.

Mari, X., Rassoulzadegan, F., Brussaard, C.P.D., Wassmann, P., 2005. Dynamics of transparent exopolymeric particles (TEP) production by Phaeocystis globosa under N- or P-limitation: a controlling factor of the retention/export balance. Harmful Algae 4, 895-914.

Marsh, M.E., 2003. Regulation of $\mathrm{CaCO}_{3}$ formation in coccolithophores. Comparative Biochemistry and Physiology B - Biochemistry \& Molecular Biology 136, 743754.

McCave, I.N., Hall, I.R., Antia, A.N., Chou, L., Dehairs, F., Lampitt, R.S., Thomsen, L., van Weering, T.C.E., Wollast, R., 2001. Distribution, composition and flux of particulate material over the European margin at $47-50^{\circ} \mathrm{N}$. Deep Sea Research Part II: Topical Studies in Oceanography 48, 3107-3139.

Mehrbach, C., Culberson, C.H., Hawley, J.E., Pytkowitz, R.M., 1973. Measurement of the apparent dissociation constants of carbonic acid in seawater at atmospheric pressure. Limnology and Oceanography 18, 897-907.

Merico, A., Tyrrell, T., Brown, C.W., Groom, S.B., Miller, P.I., 2003. Analysis of satellite imagery for Emiliania huxleyi blooms in the Bering Sea before 1997. Geophysical Research Letters 30, 1337.

Merico, A., Tyrrell, T., Cokacar, T., 2006. Is there any relationship between phytoplankton seasonal dynamics and the carbonate system? Journal of Marine Systems 59, 120-142.

Milliman, J.D., Troy, P.J., Balch, W.M., Adams, A.K., Li, Y.H., Mackenzie, F.T., 1999. Biologically mediated dissolution of calcium carbonate above the chemical lysocline? Deep Sea Research Part I: Oceanographic Research Papers 46, 16531669.

Mopper, K., Zhou, J., Sri Ramana, K., Passow, U., Dam, H.G., Drapeau, D.T., 1995. The role of surface-active carbohydrates in the flocculation of a diatom bloom in a mesocosm. Deep Sea Research Part II: Topical Studies in Oceanography 42, 4773. 
Mucci, A., 1983. The solubility of calcite and aragonite in seawater at various salinities, temperatures, and one atmosphere total pressure. American Journal of Science 283, 781-799.

Murata, A., Takizawa, T., 2002. Impact of a coccolithophorid bloom on the $\mathrm{CO}_{2}$ system in surface waters of the eastern Bering Sea shelf. Geophysical Research Letters 29, 1547. doi:10.1029/2001GL013906.

Nanninga, H. Tyrrell, T, 1996. Importance of light for the formation of alga blooms by Emiliania huxleyi. Marine Ecology Progress Series 136, 195-203.

Paasche, E., 2002. A review of the coccolithophorid Emiliania huxleyi (Prymnesiophyceae), with particular reference to growth, coccolith formation, and calcification-photosynthesis interactions. Phycologia 40, 503-529.

Passow, U., 2002. Transparent exopolymer particles (TEP) in aquatic environments. Progress in Oceanography 55, 287-333.

Passow, U., Alldredge, A.L., 1995a. A dye-binding assay for the spectrophotometric measurement of transparent exopolymer particles (TEP). Limnology and Oceanography 40, 1326-1335.

Passow, U., Alldredge, A.L., 1995b. Aggregation of a diatom bloom in a mesocosm the role of transparent exopolymer particles (TEP). Deep Sea Research Part II: Topical Studies in Oceanography 42, 99-109.

Passow, U., Alldredge, A.L., 1999. Do transparent exopolymer particles (TEP) inhibit grazing by the euphausiid Euphausia pacifica? Journal of Plankton Research 21, 2203-2217.

Purdie, D.A., Finch, M., 1994. The impact of a coccolithophorid bloom on dissolved carbon dioxide in sea water enclosures in a Norwegian fjord. Sarsia 79, 379387.

Rees, A.P., Joint, I., Donald, K.M., 1999. Early spring bloom phytoplankton-nutrient dynamics at the Celtic Sea Shelf Edge. DSR Part I 46, 483-510.

Rees, A.P., Woodward, E.M., Robinson, C., Cummings, D.G., Tarran, G.A., Joint I., 2002. Size-fractionated nitrogen uptake and carbon fixation during developing coccolithophore bloom in the North Sea during June 1999. Deep Sea Research Part II: Topical Studies in Oceanography 49, 29052927.

Reynolds, R.W., Rayner, N.A., Smith, T.M., Stokes, D.C., Wang, W.Q., 2002. An improved in situ and satellite SST analysis for climate. Journal of Climate 15 , 1609-1625.

Riebesell, U., Zondervan, I., Rost, B., Tortell, P.D., Zeebe, R.E., Morel, F.M.M., 2000 Reduced calcification of marine plankton in response of increased atmospheric $\mathrm{CO}_{2}$. Nature 407, 364-367.

Riebesell, U., Schulz, K.G., Bellerby, R.G.J., Botros, M., Fritsche, P., Meyerhofer, M. Neill, C., Nondal, G., Oschlies, A., Wohlers, J., Zollner, E., 2007. Enhanced biological carbon consumption in a high $\mathrm{CO}_{2}$ ocean. Nature 450,545-548.

Riemann, F., 1989. Gelatinous phytoplankton detritus aggregates on the Atlantic deep-sea bed. Marine Biology 100, 533-539.

Robertson, J.E., Robinson, C., Turner, D.R., Holligan, P., Watson, A.J., Boyd, P.W. Fernández, E., Finch, M., 1994. The impact of a coccolithophore bloom on oceanic carbon uptake in the northeast Atlantic during summer 1991. Deep Sea Research Part I: Oceanographic Research Papers 41, 297-314.

Sabine, C.L., Key, R.M., Feely, R.A., Greeley, D., 2002. Inorganic carbon in the Indian Ocean: distribution and dissolution processes. Global Biogeochemical Cycles 16 1067. doi:10.1029/2002GB001869.

Santschi, P.H., Hung, C.-C., Schultz, G., Alvarado-Quiroz, N., Guo, L., Pinckney, J., Walsh, I., 2002. Control of acid polysaccharide production and 234Th and POC export fluxes by marine organisms. Geophysical Research Letters 30, 10441047

Schartau, M., Engel, A., Schröter, J., Thoms, S., Völker, C., Wolf-Gladrow, D., 2007. Modelling carbon overconsumption and the formation of extracellula particulate organic carbon. Biogeosciences 4, 433-454.

Schiebel, R., Waniek, J., Zeltner, A., Alves, M., 2002. Impact of the Azores Front on the distribution of planktic foraminifers, shelled gastropods, and coccolithophorids. Deep Sea Research Part II: Topical Studies in Oceanography 49, 4035-4050.
Sciandra, A., Harlay, J., Lefèvre, D., Lemée, R., Rimmelin, P., Denis, M., Gattuso, J.-P., 2003. Response of coccolithophorid Emiliania huxleyi to elevated partial pressure of $\mathrm{CO}_{2}$ under nitrogen limitation. Marine Ecology Progress Series $261,111-122$

Simon, M., Azam, F., 1989. Protein content and protein synthesis rates of planktonic marine bacteria. Marine Ecology Progress Series 51, 201-213.

Smyth, T.J., Tyrrell, T., Tarrant, B., 2004. Time series of coccolithophore activity in the Barents Sea, from twenty years of satellite imagery. Geophysical Research Letters $31,1-4$

Tyrrell, T., Merico, A., 2004. Emiliania huxleyi: Bloom Observations and the Conditions that Induce them. In: Thierstein, H.R., Young, J.R. (Eds.) Coccolithophores. From Molecular Processes to Global Impact. Springer, pp. $75-97$.

Tyrrell, T., Holligan, P., Mobley, C.D., 1999. Optical impacts of oceanic coccolithophore blooms. Journal of Geophysical Research 104, 3223-3241.

van der Wal, P., van Bleijswijk, J.D.L., Egge, J.K., 1994. Primary productivity and calcification rate in blooms of the coccolithophorid Emiliania huxley (LOHMANN) HAY et MOHLER developing in mesocosms. Sarsia 79, 401-408.

van der Wal, P., Kempers, R.S., Veldhuis, M.J.W., 1995. Production and downward flux of organic matter and calcite in a North Sea bloom of the coccolithophore Emiliania huxleyi. Marine Ecology Progress Series 126, 247-265.

Verdugo, P., Alldredge, A.L., Azam, F., Kirchman, D.L., Passow, U., Santschi, P.H., 2004 The oceanic gel phase: a bridge in the DOM-POM continuum. Marine Chemistry $92,67-85$.

Westbroek, P., Brown, C.W., van Bleijswijk, J.D.L., Brownlee, C., Brummer, G.-J. Conte, M., Egge, J.K., Fernández, E., Jordan, R., Knappertsbusch, M., Stefels, J., Veldhuis, M.J.W., van der Wal, P., Young, J.R., 1993. A model system approach to biological climate forcing. The example of Emiliania huxleyi. Global and Planetary Change 8, 27-46.

Wollast, R. Chou, L, 1998. Distribution and fluxes of calcium carbonate along the continental margin in the Gulf of Biscay. Aquatic Geochemistry 4, 369-393.

Wollast, R., Chou, L., 2001a. Ocean Margin EXchange in the Northern Gulf of Biscay: OMEX I. An introduction. Deep Sea Research Part II: Topical Studies in Oceanography 48, 2971-2978.

Wollast, R. Chou, L., 2001b. The carbon cycle at the ocean margin in the northern Gulf of Biscay. Deep Sea Research Part II: Topical Studies in Oceanography 48 3265-3293.

Yentsch, C.S., Menzel, D.W., 1963. A method for the determination of phytoplankton chlorophyll and phaeophytin by fluorescence. Deep Sea Research and Oceanographic Abstracts 10, 221-231.

Young, J.R., Ziveri, P., 2000. Calculation of coccolith volume and its use in calibration of carbonate flux estimates. Deep-Sea Research II 47, 1679-1700.

Young, J.R., Davis, S.A., Bown, P.R., Mann, S., 1999. Coccolith Ultrastructure and Biomineralisation. Journal of Structural Biology 126, 195-215.

Ziveri, P., Broerse, A.T.C., Van Hinte, J.E., Westbroek, P., Honjo, S., 2000. The fate of coccoliths at 48 N 21 W, Northeastern Atlantic. Deep Sea Research Part II: Topical Studies in Oceanography 47, 1853-1875.

Ziveri, P., De Bernardi, B., Baumann, K.H., Stoll, H.M., Mortyn, P.G., 2007. Sinking of coccolith carbonate and potential contribution to organic carbon ballasting in the deep ocean. Deep Sea Research Part II: Topical Studies in Oceanography 54 659-675.

Zondervan, I., Rost, B., Riebesell, U., 2002. Effect of $\mathrm{CO}_{2}$ concentration on the PIC/POC ratio in the coccolithophore Emiliania huxleyi grown under light-limiting conditions and different daylengths. Journal of Experimental Biology and Ecology 272, 55-70

Zubkov, M.V., Fuchs, B.M., Archer, S.D., Kiene, R.P., Amann, R., Burkill, P.H., 2002 Rapid turnover of dissolved DMS and DMSP by defined bacterioplankton communities in the stratified euphotic zone of the North Sea. Deep Sea Research Part II: Topical Studies in Oceanography 49, 3017-3038. 